Prepared in cooperation with the U.S. Agency for International Development under the auspices of the U.S. Department of State

\title{
The Central African Republic Diamond Database-A Geodatabase of Archival Diamond Occurrences and Areas of Recent Artisanal and Small-Scale Diamond Mining
}

Open-File Report 2018-1088 
Cover. The main road west of Bambari toward Bria and the Mouka-Ouadda plateau, Central African Republic, 2006. Photograph by Peter Chirico, U.S. Geological Survey. 


\section{The Central African Republic Diamond Database-A Geodatabase of Archival Diamond Occurrences and Areas of Recent Artisanal and Small-Scale Diamond Mining}

By Jessica D. DeWitt, Peter G. Chirico, Sarah E. Bergstresser, and Inga E. Clark

Prepared in cooperation with the U.S. Agency for International Development under the auspices of the U.S. Department of State

Open-File Report 2018-1088 


\title{
U.S. Department of the Interior \\ RYAN K. ZINKE, Secretary
}

\author{
U.S. Geological Survey \\ James F. Reilly II, Director
}

U.S. Geological Survey, Reston, Virginia: 2018

For more information on the USGS - the Federal source for science about the Earth, its natural and living resources, natural hazards, and the environment-visit https://www.usgs.gov or call 1-888-ASK-USGS.

For an overview of USGS information products, including maps, imagery, and publications,

visit https://store.usgs.gov.

Any use of trade, firm, or product names is for descriptive purposes only and does not imply endorsement by the U.S. Government.

Although this information product, for the most part, is in the public domain, it also may contain copyrighted materials as noted in the text. Permission to reproduce copyrighted items must be secured from the copyright owner.

Suggested citation:

DeWitt, J.D., Chirico, P.G., Bergstresser, S.E., and Clark, I.E., 2018, The Central African Republic Diamond DatabaseA geodatabase of archival diamond occurrences and areas of recent artisanal and small-scale diamond mining: U.S. Geological Survey Open-File Report 2018-1088, 28 p., 1 pl., https://doi.org/10.3133/ofr20181088.

ISSN 2331-1258 (online) 


\section{Contents}

Abstract

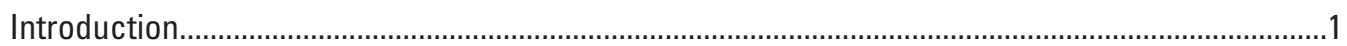

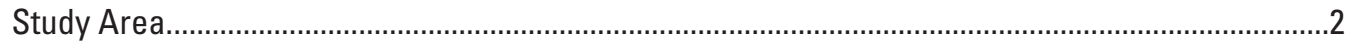

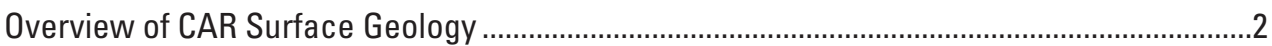

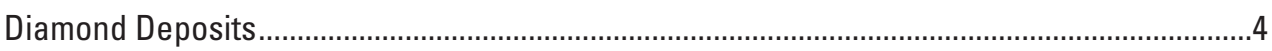

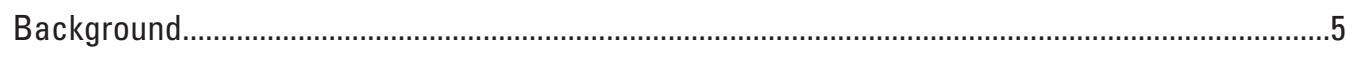

Conflict in CAR

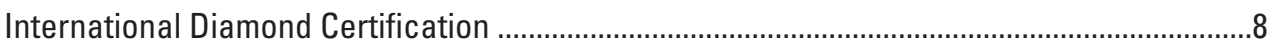

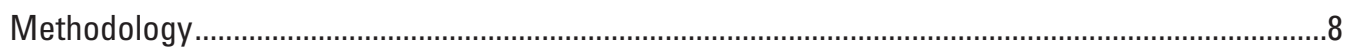

Compilation of Archival ASM and Diamond Occurrences Dataset ..........................................8

Development of Recent (2013-2017) Mining Activity Dataset.................................................12

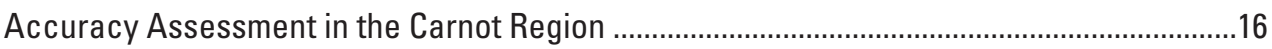

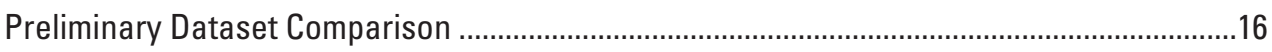

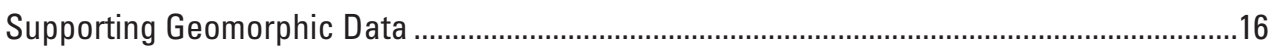

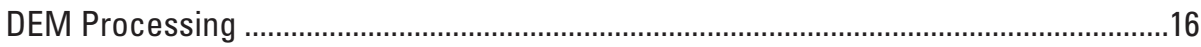

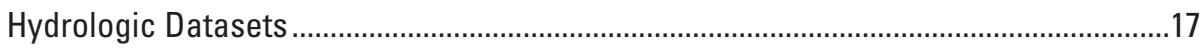

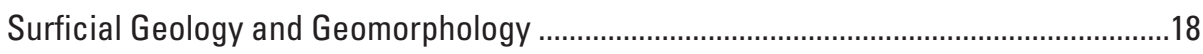

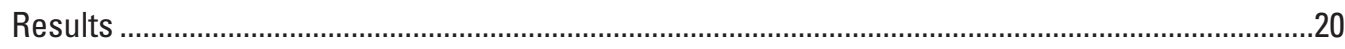

Archival ASM and Diamond Occurrence Results .............................................................20

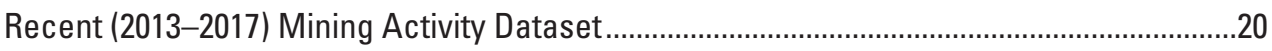

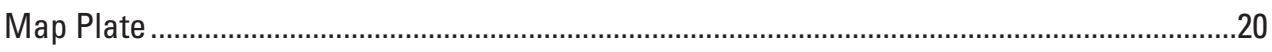

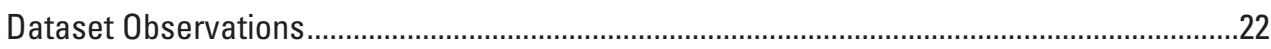

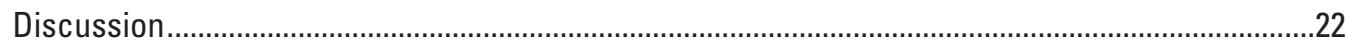

Artisanal Mining Remote Sensing Challenges ....................................................................22

Differences in Diamond Occurrence Between the Carnot and Mouka-Ouadda

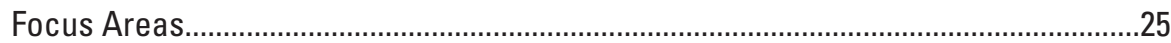

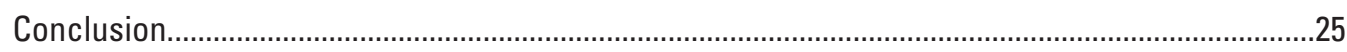

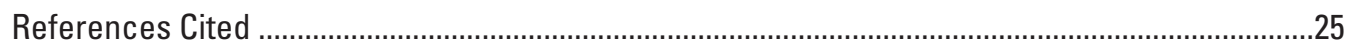

Oversize Item [available at https://doi.org/10.3133/ofr20181088]

Plate 1. Surficial and Bedrock Geology, Placer Diamond Deposits, and Mineral Occurrences of the Central African Republic

\section{Figures}

1. Map of the study area, which includes all of the Central African Republic ......................3

2. Map showing the Carnot and Mouka-Ouadda Sandstones, located in western and eastern Central African Republic, respectively...

3. Diagram showing geomorphic units of channel, alluvial flat, and terrace, which are related to the distribution of diamond deposits in the Central African Republic 
4. Map showing the 2012-13 movements of the Séléka rebel alliance and diamond deposits in the Central African Republic

5. Artisanal and small-scale mining and the sale of diamonds is permitted in Kimberley Process-designated compliant zone subprefectures, which include Berberati, Boda, Carnot, Gadzi, and Nola

6. High-resolution satellite imagery, collected between January 1, 2013, and November 28, 2017, was used for small-scale mining interpretation in the Central African Republic

7. Graph showing the number of high-resolution satellite imagery acquisition dates per year used to create the Recent Mining Activity Dataset.

8. Photographic interpretation of artisanal and small-scale mining pits is partly based on tonal and hue differentiation, where bright white, tan, or red colors indicate excavation activity and are distinctive from the darker hues of undisturbed vegetated areas.

9. Examples of geometric characteristics used to interpret mining activity in remotely sensed imagery

10. Pits may contain bright or dark-toned water, which can be used to indicate the recency of mining activity at that pit when supported by additional mining indicators

11. Example of a barrage built into a river channel to stem the flow of water to allow for the digging of pits

12. Map showing the field sites visited by the U.S. Agency for International Development's Property Rights and Artisanal Diamond Development II Project between August 1, 2016, and January 30, 2017

13. Map showing the findings of the Central African Republic Diamond Database, including the Archival Artisanal and Small-scale Mining and Diamond Occurrence Dataset and the Recent (2013-2017) Mining Activity Dataset, which describes the geographic distribution of known small-scale diamond mining activity in the Central African Republic

14. Archival artisanal and small-scale mining and Diamond Occurrence results and Recent (2013-2017) Mining Activity results mapped by subprefecture

15. Archival artisanal and small-scale mining and Diamond Occurrence results and Recent (2013-2017) Mining Activity results mapped by sixth order watersheds

\section{Tables}

1. Archival sources used to compile historical diamond occurrences .................................10

2. Attribute information included with each diamond occurrence record ..........................11

3. Numeric codes that indicate specific mining activities in the Recent (2013-2017) Mining Activity Dataset

4. Part 1 of the surficial geology and geomorphology model includes zones of relative height.

5. Part 2 of the surficial geology and geomorphology model characterizes erosive and depositional zones by incorporating slope steepness in a path-distance function..

6. Categories of geomorphic units in part 3 of the surficial geology and geomorphology model.

7. Accuracy matrix of Carnot region database points 


\title{
The Central African Republic Diamond Database- A Geodatabase of Archival Diamond Occurrences and Areas of Recent Artisanal and Small-Scale Diamond Mining
}

\author{
By Jessica D. DeWitt, Peter G. Chirico, Sarah E. Bergstresser, and Inga E. Clark
}

\begin{abstract}
The alluvial diamond deposits of the Central African Republic (CAR) are mined almost exclusively by way of informal artisanal and small-scale mining (ASM) methods. ASM sites range in diameter from a few meters to 30 meters or more, and are typically excavated by crews of diggers using hand tools, sieves, and jigs. CAR's reported annual production has ranged from 300,000 to 470,000 carats over the past decade. This production is significant for CAR because it accounts for a large portion of the country's export income and employs an estimated 60,000 to 90,000 miners nationally. Diamond production has also been linked to the violent conflict and political instability which have plagued the country for decades. The most recent conflict began in 2012 and resulted in an international embargo on the export of rough diamonds from CAR. This embargo was followed by a ceasefire and a return of peace in certain zones of the country in 2015; however, political and economic instability continues to afflict many areas of the country. International efforts to restore peace in CAR have included United Nations support as well as international technical assistance in tracking, assessing, and monitoring diamond production. In 2015, the Kimberley Process (KP) developed an operational framework allowing for legitimate exports from five subprefectures in CAR that were deemed to be compliant with KP internal controls and which were also considered to be free from systematic violence or control of armed groups.

The goal of this study was to address information gaps regarding the location and extent of diamond occurrences and mining activity through the integration of geologic research with remote sensing, geographic information systems analysis, and fieldwork. Effective and efficient monitoring of diamond mining activity using satellite imagery requires detailed understanding of the geographic distribution of diamond sources and mining activities.
\end{abstract}

\begin{abstract}
A two-phase methodology was developed to address the knowledge gaps. The first phase consisted of the creation of a comprehensive geospatial catalogue of diamond mining and occurrence locations from archival records such as historical maps, mining reports, academic publications, and field data. Building upon this locational database, the second phase consisted of the creation of a geospatial dataset cataloguing current mining activity locations through manual interpretation of recently acquired satellite imagery. The accuracy of this second geospatial dataset was then assessed using field observations made between 2016 and 2017 by the U.S. Agency for International Development's Property Rights and Artisanal Diamond Development II project. This report presents a two-part geodatabase: part 1 contains the locations of diamond mine sites and occurrences from archival sources, and part 2 indicates areas of current or recent mining activity. This geodatabase is unique in its temporal and spatial extent and may be used to analyze the geographic distribution of CAR's known diamond resources, to assess the effect of recent violent conflicts and KP actions on diamond production, to provide decision makers with information regarding small-scale diamond mining, and to improve the monitoring of mining in regions of the country prone to conflict.
\end{abstract}

\section{Introduction}

Diamond resources in the Central African Republic (CAR) occur in alluvial deposits, all of which are mined through artisanal and small-scale mining (ASM) methods. Artisanal miners employ teams of diggers to remove surficial sediment layers using hand tools such as sieves and jigs to reveal potential diamond deposits in gravel layers of the sedimentary column (Chirico and others, 2010). Diamond resources are a significant part of the country's export-based income, with reported annual exports fluctuating between 
100,000 and 450,000 carats over the past several decades (Chirico and others, 2010). In spite of these diamond resources, CAR remains one of the world's least developed countries (Central Intelligence Agency, 2016; United Nations Development Programme, 2016). Moreover, political instability has plagued the country since its independence in 1960, as evidenced by multiple coups, attempted coups, and the formation and continued presence of several armed rebel groups (Ghura and Benoît, 2004; International Crisis Group, 2007; Giroux and others, 2009; Spittaels and Hilgert, 2009). This violence has displaced more than a million people and maintained poverty-level conditions for three-quarters of CAR's 2.3 million populace (World Bank, 2017). The most recent upheaval began in 2012, when an alliance of rebel groups, known as Séléka, advanced across the country, violently seizing key infrastructure, valuable diamond production areas, and ultimately government power (International Crisis Group, 2014). The inclusion of CAR's diamond production regions in this violent upheaval led the Kimberley Process (KP), an international organization prohibiting the trade of conflict diamonds, to temporarily suspend CAR from exporting rough diamonds to the international market (Kimberley Process Certification Scheme, 2013). The concept of conflict diamonds, sometimes referred to as "blood diamonds," emerged in the 1990s to describe situations of violence and armed conflict that are financed by illegal mining and sale of diamonds (Le Billon, 2008; Chirico and Malpeli, 2014). With the return of peace and government stability in 2015, the KP revised the suspension to allow the export of diamonds from specific permitted zones, and committed to support CAR efforts to reform its diamond sector (Kimberley Process Certification Scheme, 2015b).

In order to address the full range of political, economic, social, and geographic factors involved in CAR's diamond mining sector, comprehensive understanding of the geographic distribution of diamond resources and ASM activity throughout the country is necessary. Although an inventory of diamond mining sites and diamond occurrences was created from U.S. Geological Survey (USGS) archival records and USGS/Bureau de Recherches Géologiques et Minières (BRGM) field data collected between 2006 and 2008 (Chirico and others, 2010), the study was done without the benefit of widespread high-resolution satellite imagery, predated the political conflict, and was not published as a geospatial dataset. Other research efforts and datasets related to diamond mining in CAR focus on limited geographic areas of the country and thus do not provide the necessary countryscale data.

This study presents a two-part geodatabase describing (1) archival ASM and diamond occurrence locations, ${ }^{i}$ and (2) recent (2013-2017) areas of mining activity. It provides a country-scale assessment of the geographic distribution of diamond occurrences and ASM activity. This report begins

iDataset includes locational information contained in Chirico and others (2010). with a detailed overview of CAR's relevant geology and diamond deposits, then provides additional information regarding CAR's history and political situation. Next, the methods used to compile the two-part geodatabase are described. The resultant country-scale datasets are then comparatively analyzed to describe changes in the spatial distribution of diamond mining activity in CAR that may correspond to the political conflict.

\section{Study Area}

In this study both the compilation of archival records and the interpretation of ASM activity from satellite imagery were conducted within the extent of known secondary diamond source zones in CAR (fig.1). These diamond source zones are primarily concentrated in two areas of the county: (1) a western region around the towns of Nola, Berberati, and Carnot in an area underlain by the Carnot Sandstone; and (2) an eastern region encompassing the areas near Bria, Sam Ouandja, Kembé, and Grand Nzako in areas underlain by or downstream from the Moukka-Ouadda Sandstone.

Located in the central region of the African continent, CAR is dominated by a tropical savanna climate (Köppen classification Aw), with year-round temperatures above $18^{\circ} \mathrm{C}$ $\left(65^{\circ} \mathrm{F}\right)$ and a dry winter season. Annual precipitation in this climate ranges from 1,381 millimeters ( $\mathrm{mm})$ (54 inches [in.]) in the northwestern part of the country (near Bocaranga) to $1,461 \mathrm{~mm}(58 \mathrm{in}$.) in the southeastern part of the country (near Bambouti). Climate along the southern border of the country transitions to tropical monsoon, with higher precipitation totals (averaging $1,740 \mathrm{~mm} /$ year [68.5 in/year]) owing to increased monsoonal rains, and a shorter dry season. The northern-most part of the country experiences a hot semi-arid climate, with approximately half the annual rainfall (average of $730 \mathrm{~mm} /$ year [29 in/year]) of the southern areas and hot year-round temperatures above $20^{\circ} \mathrm{C}$ (https://en.climate-data. org). Because of the large amounts of rainfall and warm temperatures, vegetation ranges from dense tropical rainforest in the southern part of the country to woody savannah in the north. The topography of CAR is dominated by low and gently rolling hills, with slightly higher elevations found in the northwest and east of the country.

\section{Overview of CAR Surface Geology}

The generalized description of surface bedrock geologic units of CAR provided in this section, together with the distribution of geomorphic units that are relevant to alluvial diamond deposits, is illustrated on the map plate. Other parts of the African continent have experienced multiple periods of extrusion, rifting, folding, and other metamorphic processes during the Precambrian and Paleozoic. However, present-day CAR is underlain by basement rocks of two cratonic nuclei, and has experienced comparatively little 


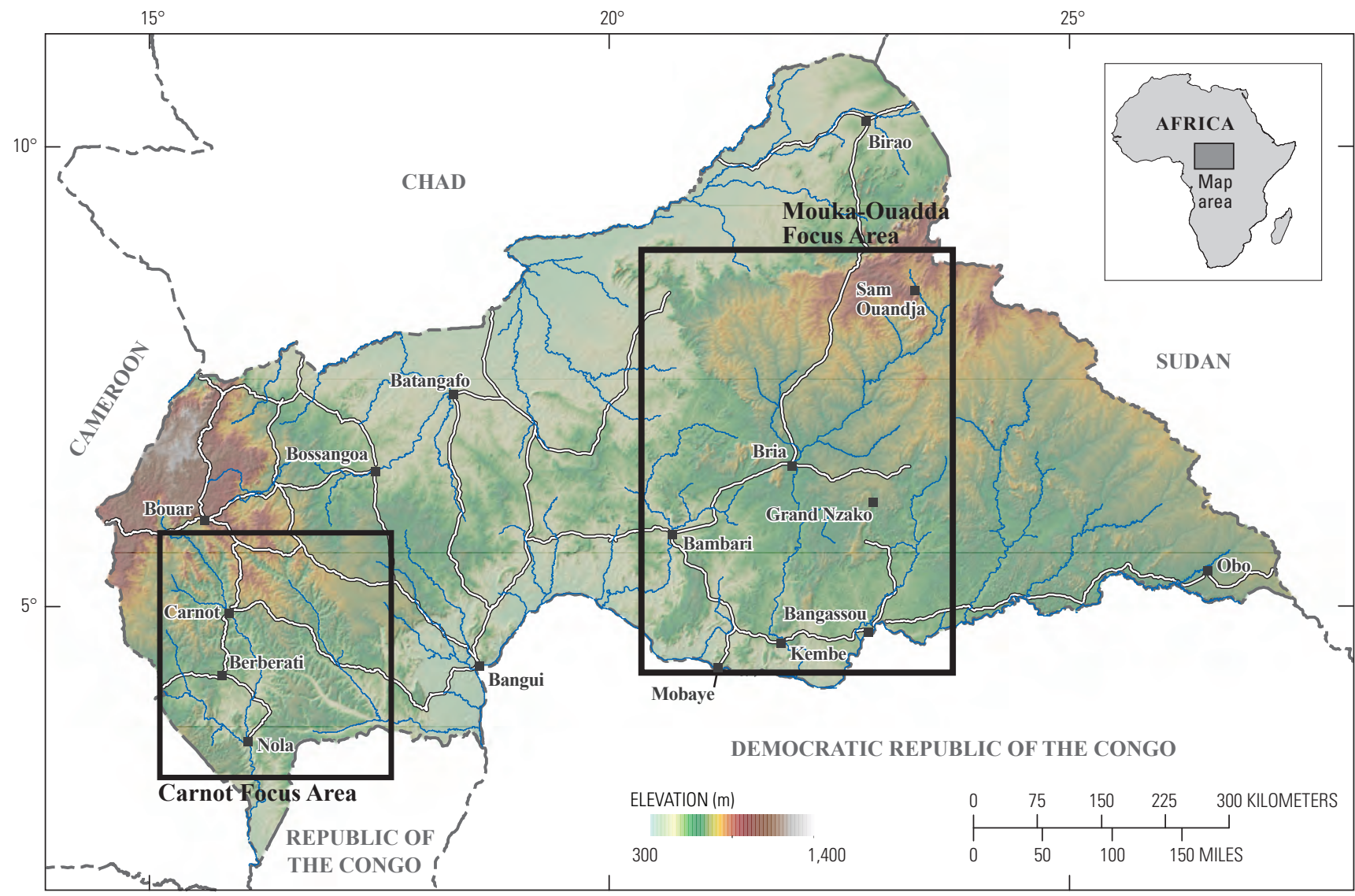

Figure 1. Map of the study area, which includes all of the Central African Republic. However, satellite image interpretation focused on the western Carnot and the eastern Mouka-Ouadda areas (shown in black outline). m, meters.

tectonic or metamorphic processes since Archean emplacement. This Precambrian basement geology consists of two major units: a lower granitic-gneissic complex and an upper schisto-quartzitic complex. The older, Neoarchean granitic-gneissic complex is primarily composed of gneisses, gneissic-migmatitic, granitic, and amphibolitic rocks, whereas the younger, Neoproterozoic schisto-quartzitic complex is composed of quartzitic and schistose rocks. These units are intruded throughout the country by Neoproterozic age rocks (Schlüter, 2006). Overlying Paleozoic units include two glaciogenic sequences, one named the Mambéré Formation located in western CAR, and the other named the Kombele Formation, located in the east. Both units range in thickness from 30 to 50 meters $(\mathrm{m})$ and are similarly composed of basal and flow tills, reworked sandstone, conglomeratic sandstone, and siltstone (Censier and others, 1992; Chirico and others, 2010).

Two Cretaceous sandstone sequences are discomforably overlain by two sequences of Cretaceous-age fluvial deposits that consist of sub-horizontal sand/conglomeratic units. One sequence is the $300-400-\mathrm{m}$ thick Carnot Sandstone located in southwest CAR and the other is the 500-m-thick MoukaOuadda Sandstone located in northeast CAR (Schlüter, 2006). These units likely extended far beyond their mapped boundaries (fig. 2 and map plate), but have eroded over time to form two distinct plateaus that cover approximately 85,000 square kilometers $\left(\mathrm{km}^{2}\right)$ in combined area (Censier and Tourenq, 1986; Censier and others, 1998; Lescuyer and Milési, 2004). The sandstone units are significant to this research because they are thought to be the secondary host rock of colluvial diamond deposits originating from Precambrian or Paleozoic kimberlitic source-rock (Censier and Tourenq, 1986; Censier and others, 1998). Following the deposition of these secondary source rocks during the Cretaceous, physical and chemical weathering has since eroded, redeposited, and concentrated the diamonds into more recent river and terrace deposits. In the Cenozoic era, these and other surficial sediments have been significantly affected by the chemical alteration that is typical of the intertropical zone and have developed lateritic duricrusts and ferricretes as much as $40 \mathrm{~m}$ thick, which extend across large portions of the country (Petit, 1985; Beauvais and Roquin, 1996). 


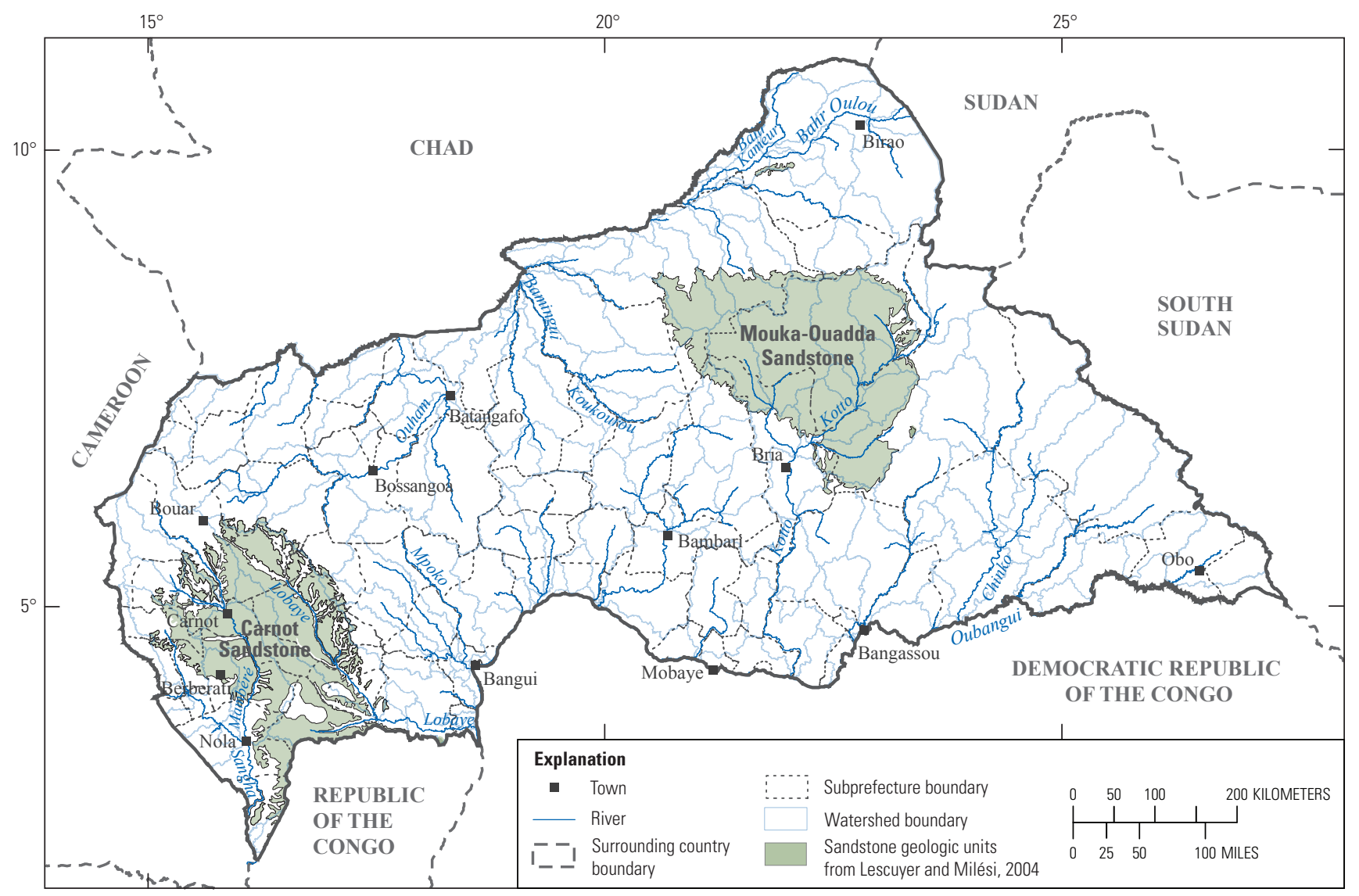

Figure 2. Map showing the Carnot and Mouka-Ouadda Sandstones, located in western and eastern Central African Republic, respectively. Each unit extends over 40,000 square kilometers or more.

\section{Diamond Deposits}

No primary sources of diamonds, such as kimberlites, lamporites, or other geologic deposits, are known to exist in CAR. Although tectonic, mineralogical, and crystallographic evidence has led to theories that undiscovered kimberlites may lie to the south of CAR in the Democratic Republic of the Congo (Censier, 1996), no direct evidence of such primary deposits exists. Currently, all known diamond deposits in CAR are alluvial. They are principally associated with the Carnot Sandstone and the Mouka-Ouadda Sandstone (see fig. 2). These two sandstone formations are considered secondary source rocks that commonly yield diamonds when eroded (Censier, 1996; Chirico and others, 2010). Efforts to sample the Carnot and Mouka-Ouadda Sandstones for diamond content thus far have been unsuccessful.

Throughout CAR, geomorphic terrain features such as alluvial flats and terraces have a varying, but increased incidence of diamond occurrence. This is in large part explained by the colluvial and fluvial erosive processes that have modified the landscape, eroding the Carnot and MoukaOuadda Sandstones, and ultimately transporting diamonds from these secondary source units to in- and near-stream alluvial deposits. Four types of alluvial placer deposits have been observed in this region, including channel deposits, alluvial flat deposits, low terrace deposits, and high terrace deposits. The geomorphology of the present landscape is an important factor in the location and quality of diamond deposits (Sutherland, 1985), and geomorphic units of alluvial flat, high- and low-terrace, colluvial hillslope, and undifferentiated bedrock (shown in fig. 3 and described below) have been incorporated into the analysis.

Surficial geomorphic units of alluvium, terrace, colluvial hillslope, and undifferentiated bedrock overlain on CAR's bedrock geology are shown on the accompanying map plate. Alluvial flats exist in proximity to the current channel location and typically have deep surficial sedimentary layers that reflect the movement of that channel across the floodplain over time. This geomorphic unit commonly hosts fluvial diamond deposits; however, such deposits may require extensive excavation owing to the potential depth of surficial sediments. Terrace geomorphic features are located at the periphery of the channel's floodplain, and are evidence of a geologically older floodplain deposit and an indication of the maximum lateral movement of the channel through time. These features may be used to interpret the locations of paleochannel positions far 

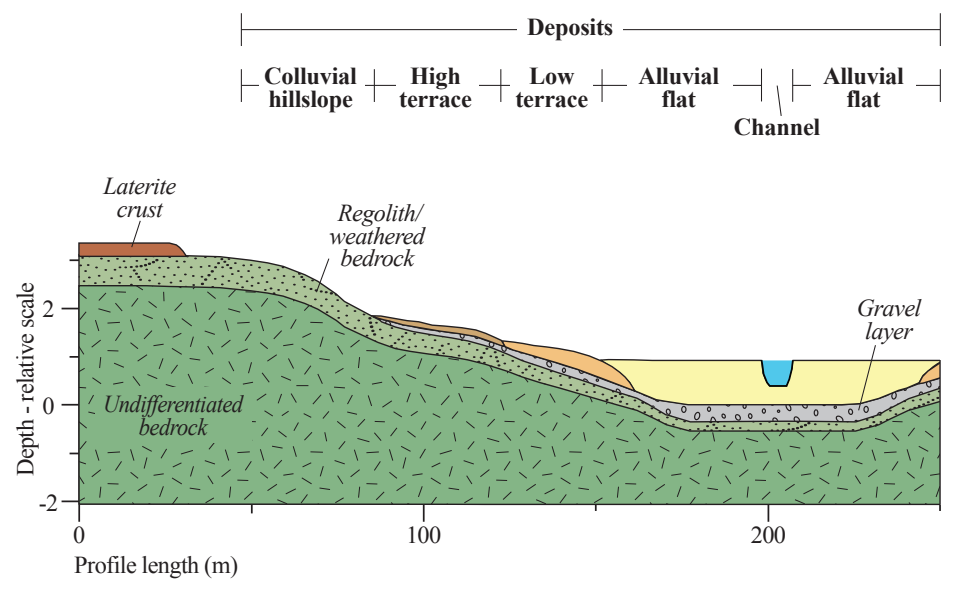

Figure 3. Diagram showing geomorphic units of channel, alluvial flat, and terrace, which are related to the distribution of diamond deposits in the Central African Republic. m, meters.

from the Quaternary channel location. Such features also may host fluvial or colluvial diamond deposits. Finally, colluvial hillslopes exist upslope of the terrace deposits and exhibit the weathered material that has been transported downslope from areas of weathered bedrock and lateritic crusts.

A majority of diamonds (85-90 percent) recovered from the alluvium near or downstream of the eastern MoukaOuadda Sandstone are reported as high to medium in quality (Bardet, 1974; Working Group of Diamond Exports, 2012), and generally larger than those recovered from the western Carnot region. In this western region three to four carat stones are more common than smaller stones, and larger stones (up to 10 carats) are not uncommon. Nevertheless, much of CAR's diamond production (65-75 percent) has been recorded as recovered from the western Carnot region (Bardet, 1974; Censier, 1996). It is possible that the higher production of the western zone could result from the higher population density and mining intensity of that region, as well as the longer history of diamond exploration and exploitation. Some reports have also suggested that unofficial export channels exist in the eastern Mouka-Ouadda region, the potential of which is exacerbated by CAR's lower institutional capacity throughout the eastern region to monitor such unofficial exports. These potential unofficial export channels could strongly influence the statistical reporting of diamonds produced from the two regions (Matthysen and Clarkson, 2013).

\section{Background}

Since its independence from France in 1960, CAR has had a tumultuous political and economic history, heavily influenced by both internal and transnational conflicts involving a multitude of national and international political actors
(Spittaels and Hilgert, 2009). A brief overview of CAR's recent history is given here as context for the datasets published in this report. Complete review of the transnational background and political situation of the greater region can be found in Giroux and others (2009), and details concerning the political actors in the region can be found in Spittaels and Hilgert (2009).

\section{Conflict in CAR}

CAR's economy has been largely driven by the export of its natural resources, including timber, diamonds, and agricultural products. Although agriculture is the primary economic activity, timber and diamond exports account for a large portion of the country's total export value (Matthysen and Clarkson, 2013). Of these key exports, diamonds are of particular international interest because of their susceptibility to theft or exploitation and the potential link to violent conflicts throughout the region. A resource's susceptibility to illicit activities, referred to as "lootability," is characterized by its relative geographic location, concentration, mode of exploitation, and value-to-weight ratio (Malpeli and Chirico, 2014).

In CAR, surficial diamond deposits are widely dispersed in hinterland regions that are distant from the capital and state regulation. Furthermore, the high value-to-weight ratio of diamonds, and the fact that they can be mined by small-scale, technologically simple methods, makes them a resource that is easily embroiled in conflict and violence (Malpeli and Chirico, 2014). International concern that CAR's diamond resources were fundamentally linked to its recent political upheavals and violent conflict was largely based on the lack of state presence and internal controls over diamond production areas, as well as the geographic links between the rebellion and areas with diamond resources (Kimberley Process Certification Scheme, 2013). 
Recent conflict in CAR has stemmed largely from the disparity between government investment in the near-capital area and the lack of presence and investment in remote parts of the country. This disparity is further complicated by a multitude of state and nonstate actors that exist throughout the country (Giroux and others, 2009; Spittaels and Hilgert, 2009). CAR's army, the Forces Armées Centrafricaines (FACA), is small and tasked with numerous security challenges, including guarding the president, guarding state prisons, protecting key infrastructure elements, and patrolling the vast remote regions of the country. In the absence of state presence in these remote regions, many armed stakeholders have emerged with a vested interest in local community or local resources. As detailed in Spittaels and Hilgert (2009), these political actors include:

- Armée Populaire pour la Restauration de la République et la Démocratie (APRD) — A rebel movement in the north and northwest of CAR, which protests intrusion by Chadian forces and the lack of CAR government response to this foreign aggression, as well as the human rights violations committed by state security services and the economic disorder created by the government.

- Union des Forces Démocratiques pour le Rassemblement (UDFR) - A rebel movement in the northeast of CAR, which disputes the lack of state investment in health care, potable water, education, transportation infrastructure, and security for the hinterland region.

- Front Démocratique du Peuple Centrafricain (FDPC) - A rebel movement that reportedly controls the main road between the towns of Kabo and Sido; the FDPC lacks a clear political agenda but reportedly has Libyan ties.

- Lord's Resistance Army (LRA)—A rebel movement not present in CAR until 2008, after gaining a foothold in the southeast; linked to violence and human rights violations throughout the southeastern part of CAR.

- Coupeurs de route-Road bandits that operate independently all over CAR, particularly in the central parts of the west and east of the country.

- Anti-balaka militias-Militia groups which began as community-based, Christian-dominant resistance to violence from Séléka Muslim rebel groups; following the official dissolution of Séléka these militia groups continued violent attacks upon CAR citizens of Muslim descent (Smith, 2014).

Each of these groups functions more-or-less independently, but together are responsible for much of the violence and conflict that occurs in CAR. The Séléka uprising is an example of violence arising from nonstate actors that heavily influenced the remote regions of the country.
In December 2012, the Séléka rebel alliance emerged in the diamond-producing town of Sam Ouandja in the northeastern part of CAR. The multitude of rebel groups that formed the alliance objected to the lack of state presence or concern for the financial, humanitarian, and security situation in remote areas of the country, as well as to the failure of President Bozizé to fulfill commitments of inclusive governance and reform. From Sam Ouandja, the armed group marched west and south towards the capital, violently taking over villages, transportation routes, resources, and diamond mining towns. A brief lull in the violence was achieved by intercession from the Chadian military, and a temporary peace agreement was established from December 2012 through January of 2013. However, the Séléka alliance resumed their violent progression shortly thereafter, ultimately seizing the capital, Bangui, and control of the CAR government in March 2013 (Shoichet, and others, 2013; International Crisis Group, 2014; Malpeli and Chirico, 2014; The Sentry, 2015). The progression of the rebellion and highlights of its movement through diamond-rich areas and control of key resources and infrastructure is shown in figure 4. Séléka seizure of the capital ousted President Bozizé, and Michel Djotodia was established as CAR's new president. Following this transition of power, the Séléka were officially disbanded; however, violence and genocide worsened between the disbanded rebel groups and Christian dominated anti-balaka militias (The Sentry, 2015).

In 2013, the KP suspended CAR from the international diamond market (discussed in the next section) (Kimberley Process Certification Scheme, 2013). Although this action had potentially serious economic ramifications for CAR, turmoil continued both in the government and throughout the country. In January 2014, President Djotodia resigned and Catherine Samba-Panza was elected interim president by the National Transition Council (Ngoupana, 2014). United Nations (U.N.) peacekeeping forces were requested to quell the violence, and in July 2014 the Séléka and anti-balaka representatives signed a cease-fire agreement. Conflict subsided, and in June 2015, the KP amended its administrative decision to allow for resumption of limited trade in rough diamonds from compliant areas of CAR (discussed in the following section) (Kimberley Process Certification Scheme, 2015a).

In March 2016, CAR held it's first-ever democratic election and declared Faustin-Archange Touadera as its new president. This successful establishment of a democratically elected president was an important step toward national stability and economic growth. However, international peacekeeping efforts from the U.N. remain an important security measure and monitoring of diamond exports and mining activity by the KP and the international community continues (World Bank, 2017). 


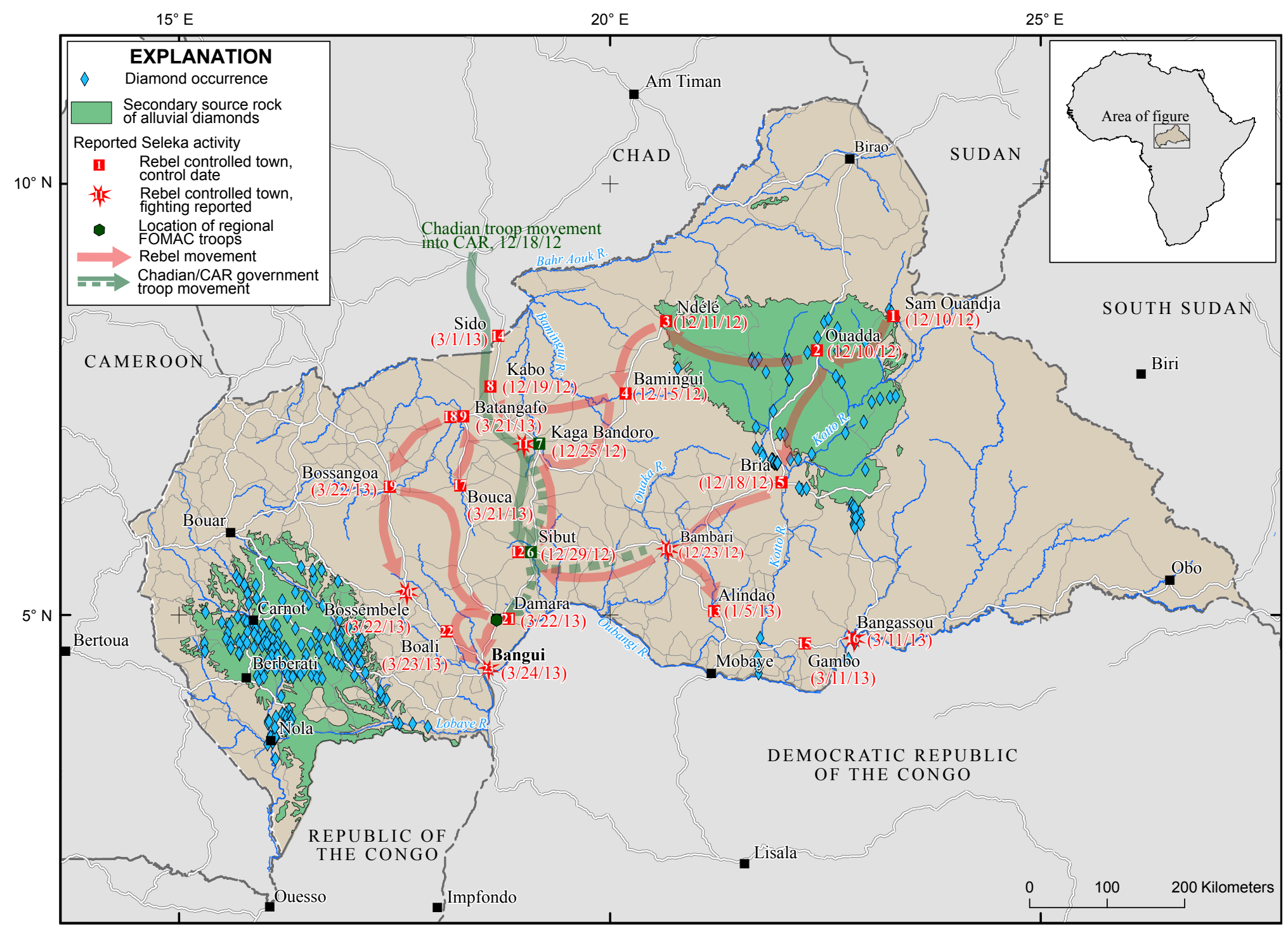

Figure 4. Map showing the 2012-2013 movements of the Séléka rebel alliance and diamond deposits in the Central African Republic. From Malpeli and Chirico (2014). 


\section{International Diamond Certification}

The Kimberley Process Certification Scheme (KPCS) is a procedure ratified and signed by more than 70 diamondproducing and diamond-importing countries, to prevent the international trade of conflict diamonds. The KPCS requires member countries to set up internal controls on their diamond trade and report their rough diamond imports and exports (Kimberley Process, 2017). These internal controls include a conflict-free certificate that must be packaged with each diamond shipment. This certification requires a documented chain of custody for packages of rough diamonds, from mine site through export, validated through signed sales slips and supply chain statistics. CAR has been a member of the Kimberley Process since the organization's inception in 2002.

In CAR, the production and export of diamonds is overseen by the Bureau d'Évaluation et de Contrôle de Diamant et d'Or (BECDOR), which was established in 1982 to oversee the diamond market and to assess the value of all gold and diamond exports. Within this system of official diamond transactions, diamonds are pulled out of the ground by teams of diggers hired and supervised by licensed mine works (ouvriers miniers). The work of multiple mine workers is directed by an artisanal miner (artisan minier), who is licensed by the government to mine for diamonds at sites smaller than $100 \mathrm{~m} \times 100 \mathrm{~m}$ using nonmechanized methods. Diamonds produced may be sold by the artisan miners either to middlemen (collecteurs), or to a mining collective (société minier). Typically, a middleman (collecteur) finances multiple artisan miners (artisan miniers) and has exclusive right to purchase diamonds from them; mining collectives (société miniers) provide support to artisanal miners (artisan miniers) within a geographic zone and buy diamonds mined in that zone. Middlemen (collecteurs) must sell to one of the few diamond exporting companies (bureaux d'achat) in CAR. From the diamond exporting company (bureau d'achat) or the mining collective (société minier), diamonds are exported to the international market. Alternately, groups of 10 or more licensed mine workers (ouvriers miniers) may license a cooperative mine site of $500 \mathrm{~m} \times 500 \mathrm{~m}$ in size and may sell diamonds produced at that site directly to the international market (Chirico and others, 2010; World Bank, 2010).

Although BECDOR was designed to establish a legal supply chain in CAR's diamond production, it is estimated that between a quarter and a half of all diamonds extracted from the ground exit the country by alternate informal trade routes (World Bank, 2010). This, in conjunction with the lack of state presence in the diamond-rich remote areas of the country and the violent events of the Séléka uprising, led to international concern over the potential use of diamonds to fund rebellion and conflict in CAR. Thus, in May of 2013, citing a lack of internal diamond sector controls to ensure that exported diamonds are conflict-free diamonds, the KP issued an administrative decision to temporarily suspend CAR from participation in the international diamond market (Kimberley Process Certification Scheme, 2013). Another administrative decision in June of 2014 provided for a detailed assessment of the volume of rough diamond production in CAR, as well as regular assessments, technical assistance, and analysis from the KP Working Group of Diamond Experts. Furthermore, it recommended enhanced vigilance for potential illicit diamond export shipments from CAR (Kimberley Process Certification Scheme, 2014).

With the return of peace and limited government stability in 2015, CAR's new government made progress in implementing multiple recommended internal controls and supply-chain monitoring measures. The KP revised its suspension of CAR from the diamond market to allow trade from subprefectures that were identified as meeting specific qualifications. Designated as compliant zones, these subprefectures were required to have implemented internal controls on the diamond sector, to allow freedom of movement for citizens, and to not have armed groups present in mining areas. Compliant zones were established and monitored by a new KP Monitoring Team made up of representatives from the KP's internal working groups (Kimberley Process Certification Scheme, 2015a,b). These compliant zones include the subprefectures of Berberati, Boda, Carnot, Gadzi, and Nola, and are located entirely in the western part of CAR (fig. 5). With the revision, the KP committed to support CAR efforts to reform its diamond sector, including enhanced vigilance measures and traceability of diamond purchases within the country as well as monitoring of mining activities to validate production reports (Kimberley Process Certification Scheme, 2015b).

\section{Methodology}

Identification and quantification of diamond mining activity sites in CAR was achieved through a two-part process. First, archival diamond occurrence records were reviewed to identify historical diamond mining sites and other areas of known diamond occurrences. Then, the geographic areas containing known diamond occurrences were used to develop zones for which high-resolution satellite imagery could be acquired. High-resolution imagery was acquired for areas within the diamond mining zones and recently active mine sites were manually interpreted. The details of this two-step procedure are described in the following sections.

\section{Compilation of Archival ASM and Diamond Occurrences Dataset}

Locations of historical ASM activity and diamond occurrences were compiled into the Archival Diamond Occurrence point geodatabase from a variety of published and unpublished data sources. For the purpose of this study, a diamond occurrence is defined as a location where diamonds have been recovered through geochemical sampling, mineral exploration, or mining activity. Source records of historical diamond occurrences are diverse and may include fieldwork, reports 


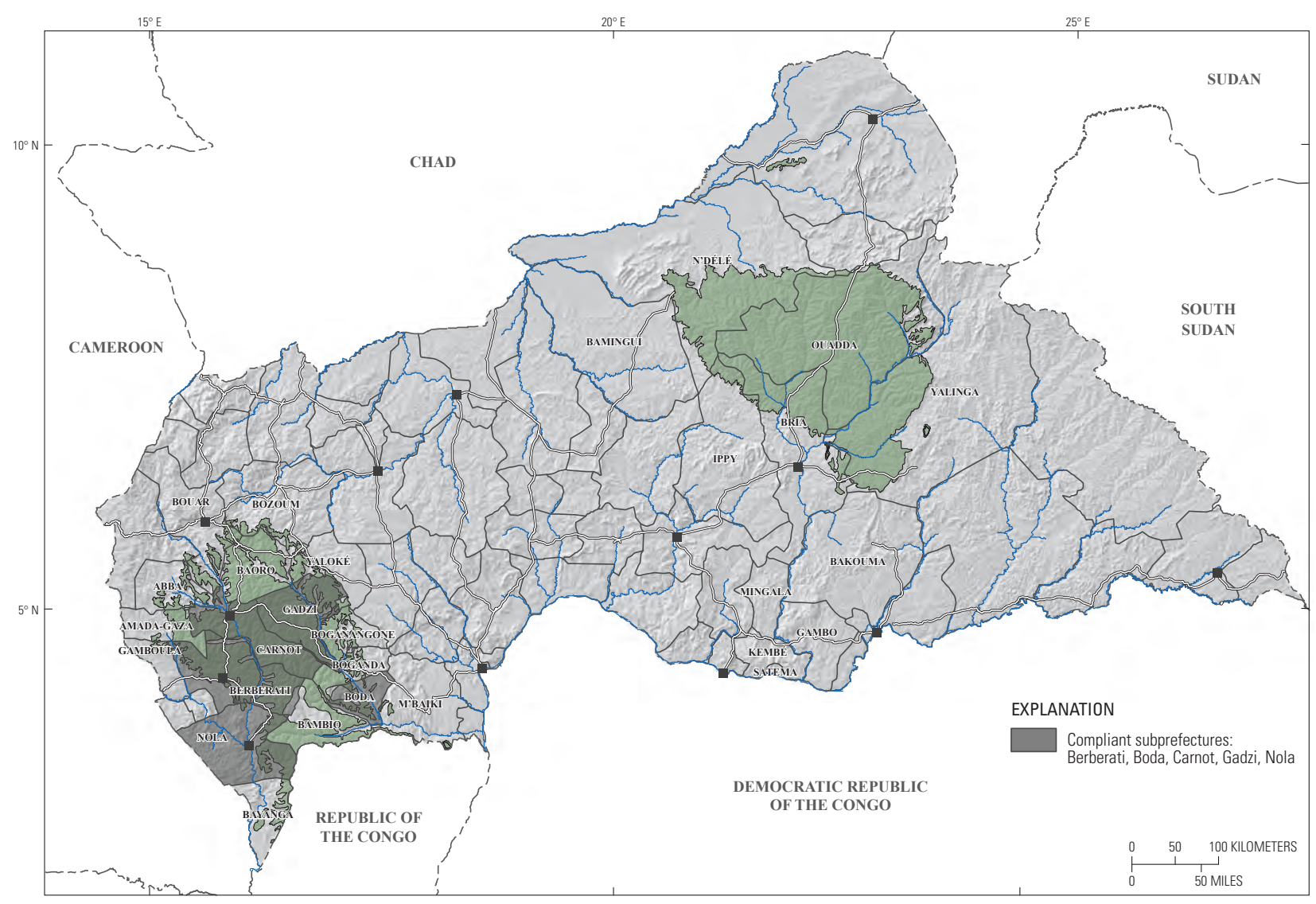

Figure 5. Artisanal and small-scale mining and the sale of diamonds is permitted in Kimberley Process-designated compliant zone subprefectures, which include Berberati, Boda, Carnot, Gadzi, and Nola.

of artisanal mine sites, sampling records from private mining companies, geologic maps, and mine sites interpreted from satellite imagery prior to 2013. The complete list of sources used to establish this geodatabase are described in table 1.

Owing to differences in the geographic scale, quality, and type of source information, the diamond occurrence locations collected in this component have varying accuracy. For example, a small-scale $(1: 6,000,000)$ map may display multiple diamond mine sites aggregated together to a single symbol, whereas a large-scale $(1: 50,000)$ map of the same mine sites might display each site as a separate symbol. In this example, the level of aggregation in the original source determines the accuracy of the locational information collected from that source. Thus, the point location established as a diamond occurrence in the Archival Diamond Occurrence dataset may be indicative of a single artisanal diamond mine, a single location where diamonds have been found, the central location of many mine sites, or a general area where small-scale diamond mining has been recorded. As a second example of this varying level of accuracy, textual information sources that specify the geographic location of a diamond occurrence are limited by the precision of the global positioning system (GPS) or map used to determine the coordinates. To maximize the locational accuracy of diamond occurrences from map sources, this study scanned maps into a digital format using a high-resolution, large format scanner, then geographically registered them using the latitude and longitude coordinates displayed on the map. Map projection and datum transformations were performed so that each map was converted from its native projection into a georeferenced database utilizing the current map projection and datum. Attributes describing the source of the diamond occurrence information, the type of diamond record, and the geographic coordinates of its location were recorded for each entry in the geodatabase. Each of these attributes and their values are fully described in table 2. Of particular note, the Source attribute contains author and publication year information, which links each record to its complete reference citation in table 1 . The Source_Cat attribute describes the type of diamond reference using generalized categories of article, field data, map, map and text, report, or satellite imagery. Finally, the Type attribute provides additional information regarding what diamond information was contained in the source material. To simplify, three categories of data type were used: ASM site, field sample, and occurrence. The category ASM site is used for all records of Source_Cat satellite imagery, as there is no way to verify the presence or absence of diamonds solely from the satellite imagery. 
Table 1. Archival sources used to compile historical diamond occurrences.

[N/A, not available; ASM, artisanal and small-scale mining]

\begin{tabular}{|c|c|c|c|c|c|}
\hline Author(s) & Title & Source type & Scale & Date & Data type \\
\hline A.C.A. HOWE International, LTD & $\begin{array}{l}\text { Summary report of the Exploration of } \\
\text { the Bamingui-Bangoran Diamond } \\
\text { Property }\end{array}$ & Report & $\mathrm{N} / \mathrm{A}$ & 1993 & Field sample \\
\hline Blanchot, A., Dumas, J., and Papon, A. & $\begin{array}{l}\text { Carte géologique de reconnaissance } \\
\text { de l'Afrique de l'ouest }\end{array}$ & Map & $1: 2,000,000$ & 1973 & Occurrence \\
\hline Boulvert, Y. & $\begin{array}{l}\text { Étude géomorphologique de la } \\
\text { République centrafricaine, Carte à } \\
1 / 1000000 \text { en duex feuilles ouest } \\
\text { et est }\end{array}$ & Map and text & $1: 1,000,000$ & 1996 & Occurrence \\
\hline $\begin{array}{l}\text { Bureau de Recherches Géologiques et } \\
\text { Minières }\end{array}$ & $\begin{array}{l}\text { Carte des gîtes minéraux du Zäire: à } \\
\text { l'échelle du } 2000000^{\circ}\end{array}$ & Map & $1: 2,000,000$ & 1976 & Occurrence \\
\hline $\begin{array}{l}\text { Bureau de Recherches Géologiques et } \\
\text { Minières }\end{array}$ & $\begin{array}{l}\text { Geologie et principales mineralisa- } \\
\text { tions d'afrique centrale }\end{array}$ & Map & $1: 4,000,000$ & 2004 & Occurrence \\
\hline Brown, C. & $\begin{array}{l}\text { Bania Survey plan and geomorpho- } \\
\text { logical interpretation, CAREMI } \\
\text { S.A.R.L. }\end{array}$ & Map & $1: 5,000$ & 1983 & Field sample \\
\hline CAREMI S.A.R.L. & $\begin{array}{l}\text { Permis de Recherches Type A., } \\
\text { Mambere Bouli RC4 173, Prospec- } \\
\text { tion de diamant dans la vallee de la } \\
\text { riviere Bouli, Survey Plan }\end{array}$ & Map & $1: 5,000$ & 1983 & Field sample \\
\hline Censier, C. & $\begin{array}{l}\text { Distribution des exploitations } \\
\text { alluvionnaires diamantiferes } \\
\text { anciennes et actuelles dans l'oueest } \\
\text { de la republique centrafricaine et le } \\
\text { sud-est cameroun }\end{array}$ & Map & $\mathrm{N} / \mathrm{A}$ & 1991 & Occurrence \\
\hline $\begin{array}{l}\text { Censier, C., Michel, J.C., and } \\
\text { Lamouille, B. }\end{array}$ & $\begin{array}{l}\text { Rapport final du projet d'appui au } \\
\text { secteur artisanal du diamante } \mathrm{n} \\
\text { République Centrafricaine } \\
\text { (PASAD) }[01 / 09 / 96-31 / 08 / 98]\end{array}$ & Report & $\mathrm{N} / \mathrm{A}$ & 1998 & Occurrence \\
\hline Martini, J., and Bowles, M. & $\begin{array}{l}\text { Metallogenic map of the Republic of } \\
\text { Congo }\end{array}$ & Map & $1: 1,000,000$ & 1994 & Occurrence \\
\hline Mestraud, J., and Bessoles, B. & $\begin{array}{l}\text { Carte gélogique de la République } \\
\text { centrafricaine } \\
\text { (Géologie et ressources minérales } \\
\text { de la République Centrafricaine- } \\
\text { État des connaissances à fin 1963: } \\
\text { Mémoires du BRGM) }\end{array}$ & Map and text & $1: 1,500,000$ & 1982 & Occurrence \\
\hline $\begin{array}{l}\text { Milési, J., Toteu, S.F., Deschamps, } \\
\text { Y., Feybesse, J., Lerouge, C., } \\
\text { Cocherie, A., Tchameni, R., Moloto- } \\
\text { A-Kenguemba, G., Kampunzu, F., } \\
\text { Nichol, N., Duguey, E., Leistel, J., } \\
\text { Saint-Martin, M., Ralay, F., Heinry, C., } \\
\text { Doumnang, Mbaigane, J., Chêne, F. } \\
\text { Monthel, J., Boutin, P., and Rolin, P. }\end{array}$ & $\begin{array}{l}\text { Geology and major ore deposits of } \\
\text { central Africa: 1:4,000,000 scale }\end{array}$ & Map & $1: 4,000,000$ & 2004 & Occurrence \\
\hline Nguimalet, C. & $\begin{array}{l}\text { Dynamique et Impacts de l'extraction } \\
\text { du diamant dans les lits fluviaux } \\
\text { des rivières Boungou et Pipi en } \\
\text { République Centrafricaine }\end{array}$ & Journal article & $\mathrm{N} / \mathrm{A}$ & 2004 & Occurrence \\
\hline $\begin{array}{l}\text { U.S. Agency for International } \\
\text { Development }\end{array}$ & $\begin{array}{l}\text { Property Rights and Diamond } \\
\text { Development (PRADD) Fieldwork } \\
\text { Boda Step } 1 \text { and } 2\end{array}$ & Field data & $\mathrm{N} / \mathrm{A}$ & 2008 & Mine site \\
\hline $\begin{array}{l}\text { U.S. Agency for International } \\
\text { Development }\end{array}$ & $\begin{array}{l}\text { Property Rights and Diamond } \\
\text { Development (PRADD) Fieldwork } \\
\text { Nola, Step } 1\end{array}$ & Field data & $\mathrm{N} / \mathrm{A}$ & 2010 & Mine site \\
\hline
\end{tabular}


Table 1. Archival sources used to compile historical diamond occurrences.-Continued

[N/A, not available; ASM, artisanal and small-scale mining]

\begin{tabular}{|c|c|c|c|c|c|}
\hline Author(s) & Title & Source type & Scale & Date & Data type \\
\hline U.S. Geological Survey & $\begin{array}{l}\text { Field Observations for Kimberley } \\
\text { Process Initiatives }\end{array}$ & Field data & $\mathrm{N} / \mathrm{A}$ & 2007 & Field sample \\
\hline U.S. Geological Survey & $\begin{array}{l}\text { ASM sites interpreted from high- } \\
\text { resolution satellite imagery } \\
\text { acquired in } 2013\end{array}$ & $\begin{array}{l}\text { Satellite } \\
\text { imagery }\end{array}$ & $\begin{array}{l}2-5 \text { meter } \\
\text { spatial } \\
\text { resolution }\end{array}$ & 2013 & Mine site \\
\hline Vaaldiam Resources, Ltd. & Annual Report 2005 & Report & $\mathrm{N} / \mathrm{A}$ & 2005 & Field sample \\
\hline Yarmolyuk, V. & Map of Mineral Resources of Africa & Map & $1: 5,000,000$ & 1980 & Occurrence \\
\hline
\end{tabular}

Table 2. Attribute information included with each diamond occurrence record.

\begin{tabular}{|c|c|c|}
\hline Attribute name & Label & Description \\
\hline OBJECTID & Integer with values $1-2,604$ & $\begin{array}{l}\text { Unique identification number that was assigned to each diamond occur- } \\
\text { rence record in the geodatabase. }\end{array}$ \\
\hline SHAPE & Point & Geometry of GIS record; all diamond occurrence records are points. \\
\hline UniqueID & Alphanumeric code & $\begin{array}{l}\text { Unique identification code for each diamond occurrence record tying it to } \\
\text { its source data. }\end{array}$ \\
\hline Source_Dat (Source Date) & Year & $\begin{array}{l}\text { Year in which the source of the diamond occurrence record was published } \\
\text { or produced. }\end{array}$ \\
\hline \multicolumn{3}{|c|}{ Source_Cat (Source Category) } \\
\hline & Article & Textual record published in a peer-reviewed journal. \\
\hline & Field data & $\begin{array}{l}\text { In situ observation by the U.S. Geological Survey or U.S. Agency for } \\
\text { International Development. }\end{array}$ \\
\hline & Map & $\begin{array}{l}\text { Cartographic product with points or polygons indicating areas of diamond } \\
\text { mining; Type may be ASM site or Diamond Occurrence. }\end{array}$ \\
\hline & Map and text & $\begin{array}{l}\text { Cartographic product with points or polygons indicating areas of diamond } \\
\text { mining, accompanied by textual report of mineral resources. }\end{array}$ \\
\hline & Misc & Other format not listed here. \\
\hline & Report & $\begin{array}{l}\text { Documented observations from a mining company or other informal } \\
\text { publication; Type is Field Sample. }\end{array}$ \\
\hline & Satellite imagery & $\begin{array}{l}\text { Observation of artisanal and small-scale mining (ASM) indicators in } \\
\text { very high resolution (VHR) panchromatic or multispectral satellite } \\
\text { imagery-see Interpretation of Recent (2013-2017) Mining Activity } \\
\text { section for details; Type is ONLY ASM site. }\end{array}$ \\
\hline \multicolumn{3}{|l|}{ Type (Observation Type) } \\
\hline & ASM Site & $\begin{array}{l}\text { Indicates a location at which diamond ASM mining was observed, but } \\
\text { without specific information regarding the presence or absence of } \\
\text { diamonds at the site. }\end{array}$ \\
\hline & Field Sample & $\begin{array}{l}\text { Indicates a location at which detailed observations have been made of } \\
\text { surficial geology and (or) diamond resources, typically from a report. }\end{array}$ \\
\hline & Occurrence & $\begin{array}{l}\text { Generic diamond occurrence indicating a location at which diamonds } \\
\text { have been recovered or observed. }\end{array}$ \\
\hline Latitude & & $\begin{array}{l}\text { Y coordinate of the diamond occurrence, in World Geodetic System } 1984 \\
\text { (WGS 84). }\end{array}$ \\
\hline Longitude & & $\begin{array}{l}\text { X coordinate of the diamond occurrence, in World Geodetic System } 1984 \\
\text { (WGS 84). }\end{array}$ \\
\hline N_UTM34N & & $\begin{array}{l}\text { Northing coordinate of the diamond occurrence, in Universal Transverse } \\
\text { Mercator (UTM) Zone } 34 \text { North of WGS } 84 \text {. }\end{array}$ \\
\hline E_UTM34N & & $\begin{array}{l}\text { Easting coordinate of the diamond occurrence, in Universal Transverse } \\
\text { Mercator (UTM) Zone } 34 \text { North of WGS } 84 \text {. }\end{array}$ \\
\hline
\end{tabular}




\section{Development of Recent (2013-2017) Mining Activity Dataset}

The Archival ASM and Diamond Occurrence Dataset was used to identify diamondiferous geographic areas, which were designated as areas of interest (AOIs). Specifically, watershedsii that contained multiple Archival ASM and Diamond Occurrence points were considered diamondiferous. Highresolution satellite imagery collected between January 1, 2013, and November 28, 2017, was then used to manually interpret mining activity within a subset of these diamondiferous AOIs. Although the full extent of the Carnot and Mouka-Ouadda Sandstone units could not be covered by high-resolution satellite imagery, nearly 30 percent of the area of this region was included (fig. 6), and in many cases imagery was acquired

ii All known diamond deposits in CAR are secondary alluvial deposits, which are weathered primarily through fluvial processes. Moreover, specific units of the surficial geomorphic landscape, such as near-stream alluvial flats and low terraces, have increased incidence of diamond occurrence. For this reason, hydrologic watersheds were selected as the spatial unit of analysis in this study. Specifically, sixth order watersheds were used to delimit areas of drainage by a river with high carrying capacity. See subsection Supporting Geomorphic Data for the methods used to delineate watersheds. beyond the extent of the mapped sandstone units to account for potentially diamondiferous areas downstream.

Between January 2013 and December 2016, 894 highresolution satellite images were acquired covering nearly $60,000 \mathrm{~km}^{2}$ of the country. Of this total, 49 percent (437 images) were acquired for the western CAR region and cover approximately half of the Carnot Sandstone area $\left(43,097 \mathrm{~km}^{2}\right)$. The remaining 51 percent (457 images) cover specific parts of the eastern CAR region, including several areas of the Mouka-Ouadda Sandstone $\left(26,540 \mathrm{~km}^{2}\right)$. The acquired imagery was collected on 97 different dates between 2013 and 2017, with the majority of these dates occurring from 2015 to 2017. The graph in figure 7 shows the number of satellite images acquired for eastern CAR, western CAR, and in total, for each year between 2013 and 2017.

Interpretation of currently active diamond mining throughout CAR was based on multiple spectral, geometric, and contextual features or characteristics that are common to informal small-scale mining of alluvial diamond deposits (Chirico and Malpeli, 2013; Kauffmann and others, 2014). The most basic of these characteristics is a distinct tonal or hue variation between the typical dark tones and colors of undisturbed vegetated ground and the bright white and tan

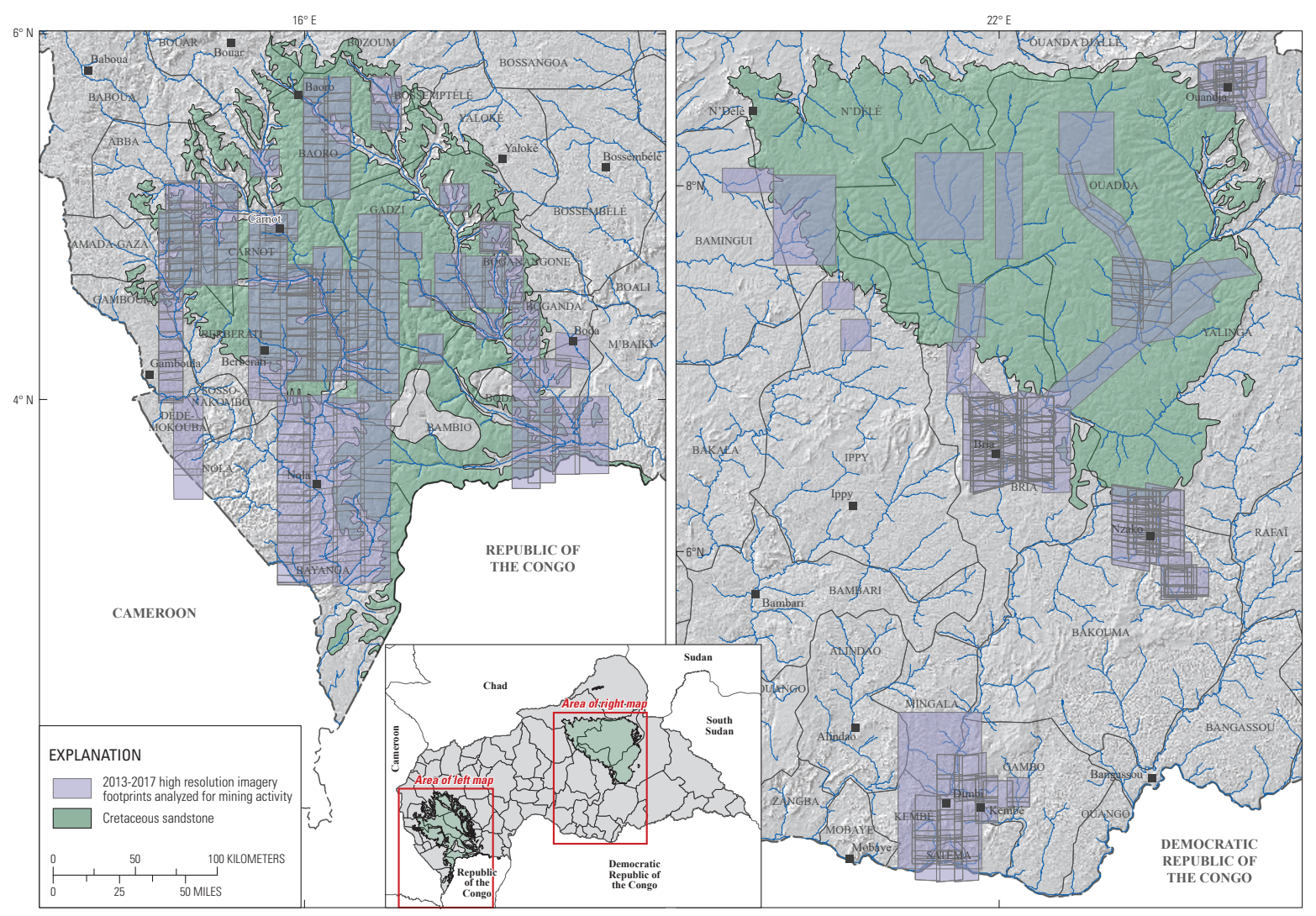

Figure 6. High-resolution satellite imagery (area of coverage represented by purple areas), collected between January 1, 2013, and November 28, 2017, was used for small-scale mining interpretation in the Central African Republic. 


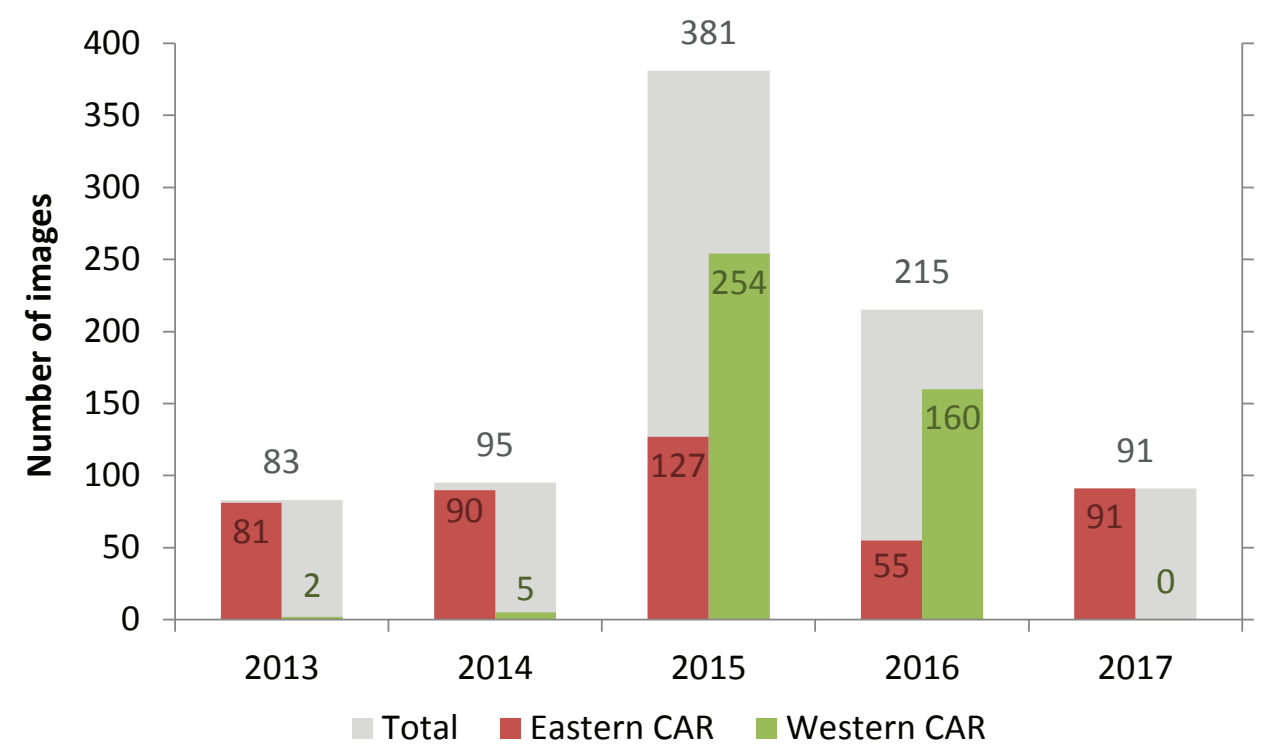

Figure 7. Graph showing the number of high-resolution satellite imagery acquisition dates per year used to create the Recent Mining Activity Dataset. CAR, Central African Republic.

(or gray in panchromatic imagery) appearance of active mining areas. The high reflectance and brightness associated with these areas is a result of the removal of vegetation and topsoil layers, as well as the excavation of subsoil sediments. There is commonly a substantial difference between the very bright tan to white hues associated with quartz-rich sandy sediments deposited in floodplains by stream channels, and the reddishbrown hues of the ferricrete and upper sedimentary layers of terrace geomorphic landforms. An example of the distinct hue and tonal differences between mine sites in the floodplain and those occurring in terraces can be seen in figure 8 .

The geometric characteristics of the pit feature are an important indication of the recency and amount of mining activity at a mine site. Because pit walls tend to collapse over time due to erosion during precipitation and the subsequent infiltration of groundwater, the presence of well-defined, linear or rectangular pit walls and sharp corner angles are an indication of current or recent mining activity. The presence of stair-step patterns within the pit, referred to as "benching," indicates a substantial amount of recent mining activity, as this pattern is characteristic of very large and deep pits. The shadows cast by these pit features are used to indicate depth of the pit below ground surface. These geometric characteristics are all evident in the mining activity shown in figure 9.

Water, interpreted by smoother texture and darker tone than excavated sediments, is frequently present inside of pit features. Bright tone and (or) brown color can be used to interpret the suspension of sediments in the water (fig. 10). This water turbidity is generally interpreted as an indication of some type of activity at a mine site, including the indication that excavated gravels are being washed to find diamonds. However, it should be noted that turbid water may also result from other, unrelated environmental factors, so the interpretation of current mining activity, as well as specific mining activities like washing, is tentative unless supported by additional activity indicators.

Additional indicators of a mine site's level of activity include (but are not limited to): extensive and well-defined paths and transportation networks, adjacent active or inactive pits, barrage or temporary dam features built into stream channels to reduce water flow for in-stream mining (as in fig. 11), the presence of pumps and (or) hoses indicating removal of water from a pit, and the presence of other excavation equipment or machinery. Based on these interpretation criteria, sites that were interpreted as recently active were included in the Recent (2013-2017) Mining Activity Dataset.

In the Archival Diamond Occurrence Dataset, each point indicates the specific location of a diamond occurrence or ASM activity. However, in the Recent (2013-2017) Mining Activity Dataset, each point describes the centroid of a $1 \mathrm{~km}^{2}$ area, containing one or more active small-scale mining sites. The Recent (2013-2017) Mining Activity Dataset was compiled by initially generating a grid of $1 \mathrm{~km}^{2}$ polygon gridcells over the full extent of CAR. A subset of these gridcells, including those in close proximity (1,000 m radius) of gridcells containing Archival Diamond Occurrence points, was selected for further analysis. High-resolution satellite imagery acquired between 2013 and 2017 was then interpreted within this subset area, and the locations exhibiting recent mining activity were identified. Gridcells that were not within the subset area or did not contain active mine sites were removed from the dataset. Details of the mining activity interpreted within each $1 \mathrm{~km}^{2}$ gridcell were attributed to its centroid point. These attributes include the number of mine sites observed, a 


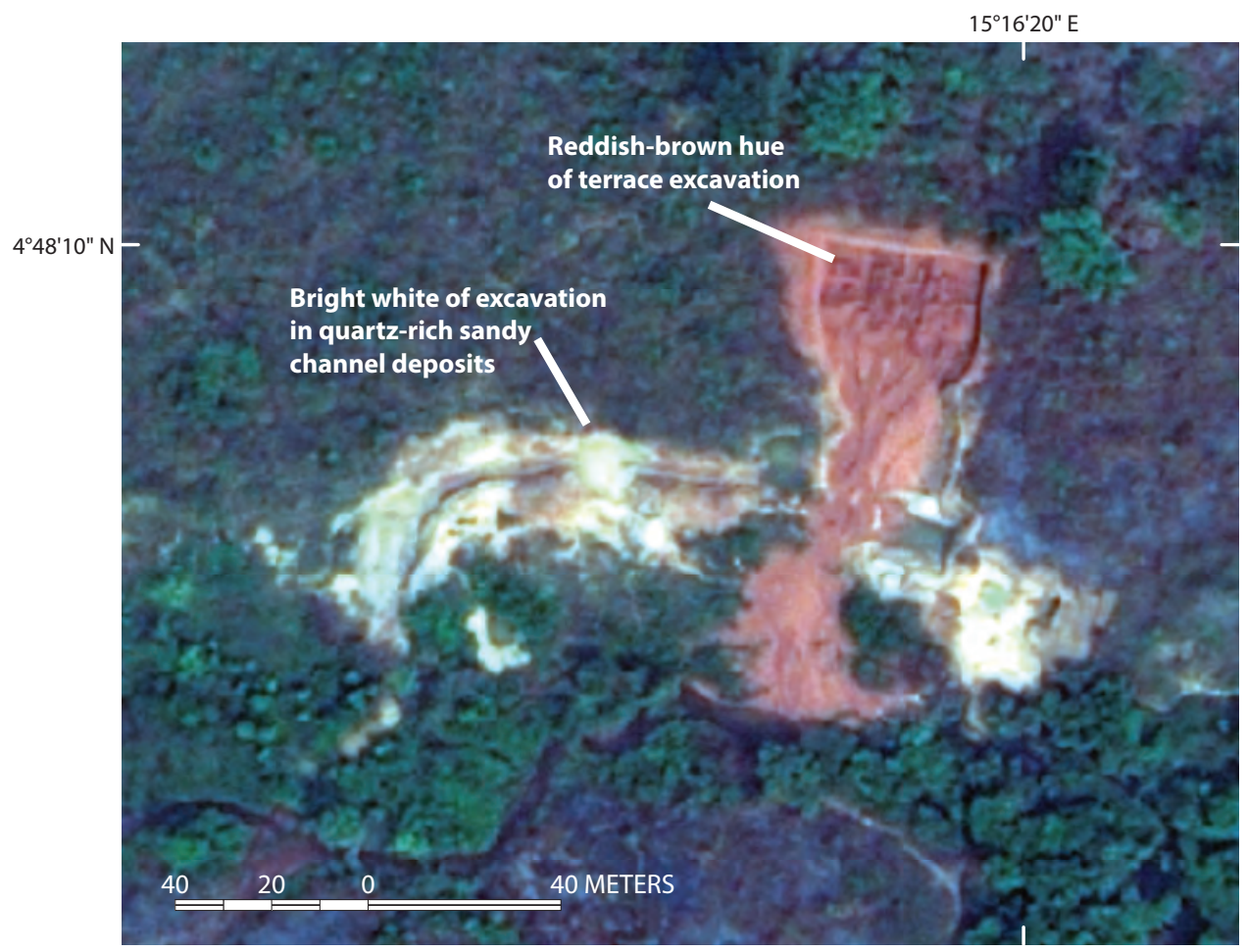

Figure 8. Photographic interpretation of artisanal and small-scale mining pits is partly based on tonal and hue differentiation, where bright white, tan, or red colors indicate excavation activity and are distinctive from the darker hues of undisturbed vegetated areas. Satellite imagery of an area in the Amada-Gaza subprefecture of CAR from DigitalGlobe's WorldView-2 satellite, February 21, 2016.

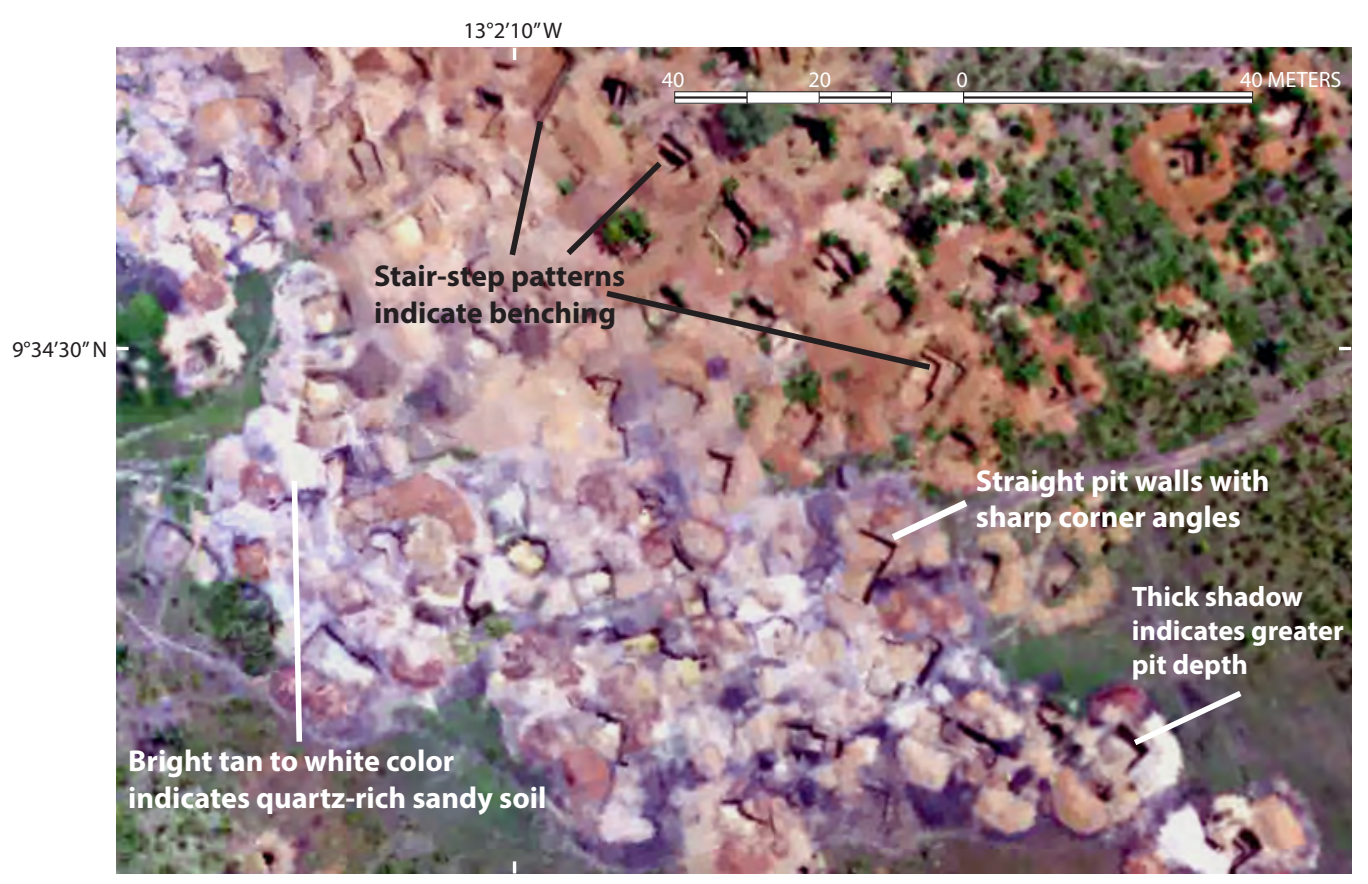

Figure 9. Examples of geometric characteristics used to interpret mining activity in remotely sensed imagery. Image resolution is 0.1 meter and was acquired by a small, unmanned aerial system near Siratoumany, Guinea (Chirico and DeWitt, 2017). 


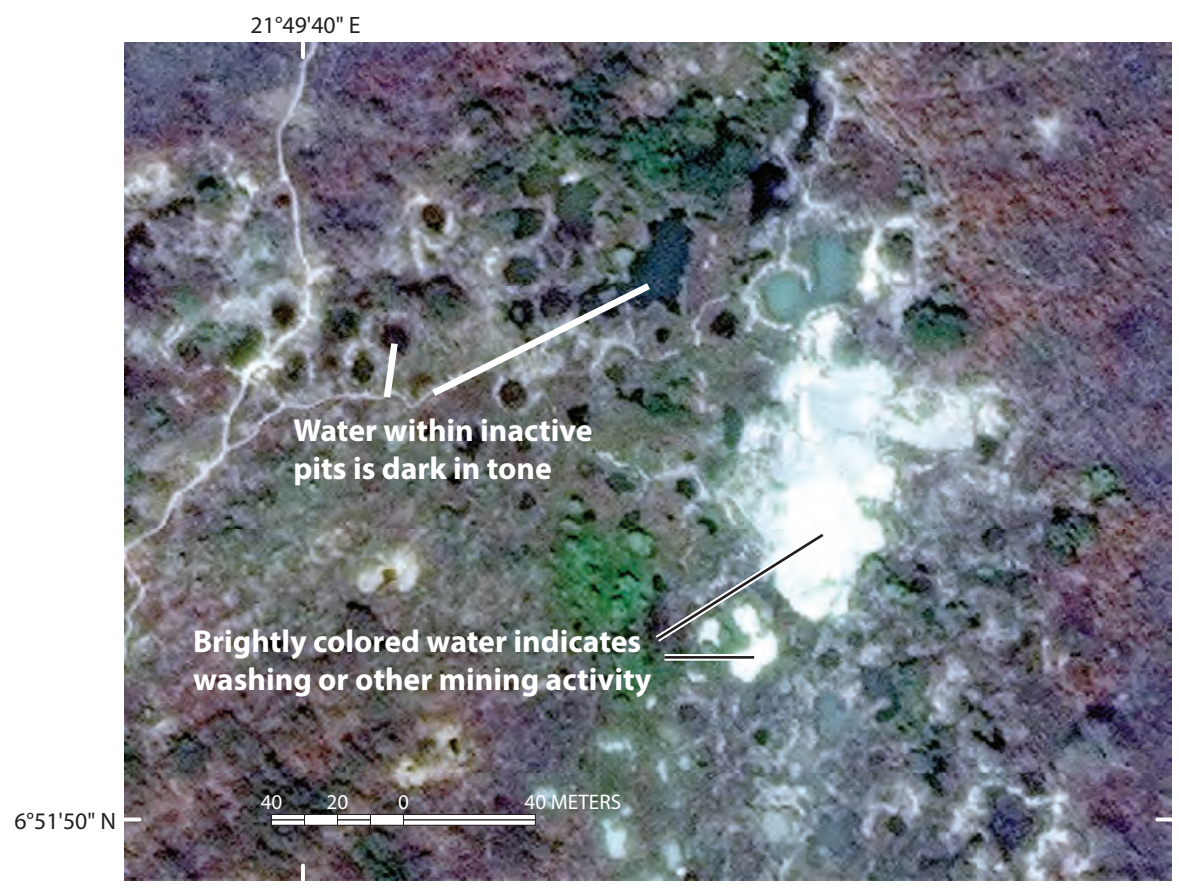

Figure 10. Pits may contain bright or dark-toned water, which can be used to indicate the recency of mining activity at that pit when supported by additional mining indicators. Satellite imagery of an area in the Bria subprefecture of CAR from DigitalGlobe's GeoEye-1 satellite, March 24, 2015.

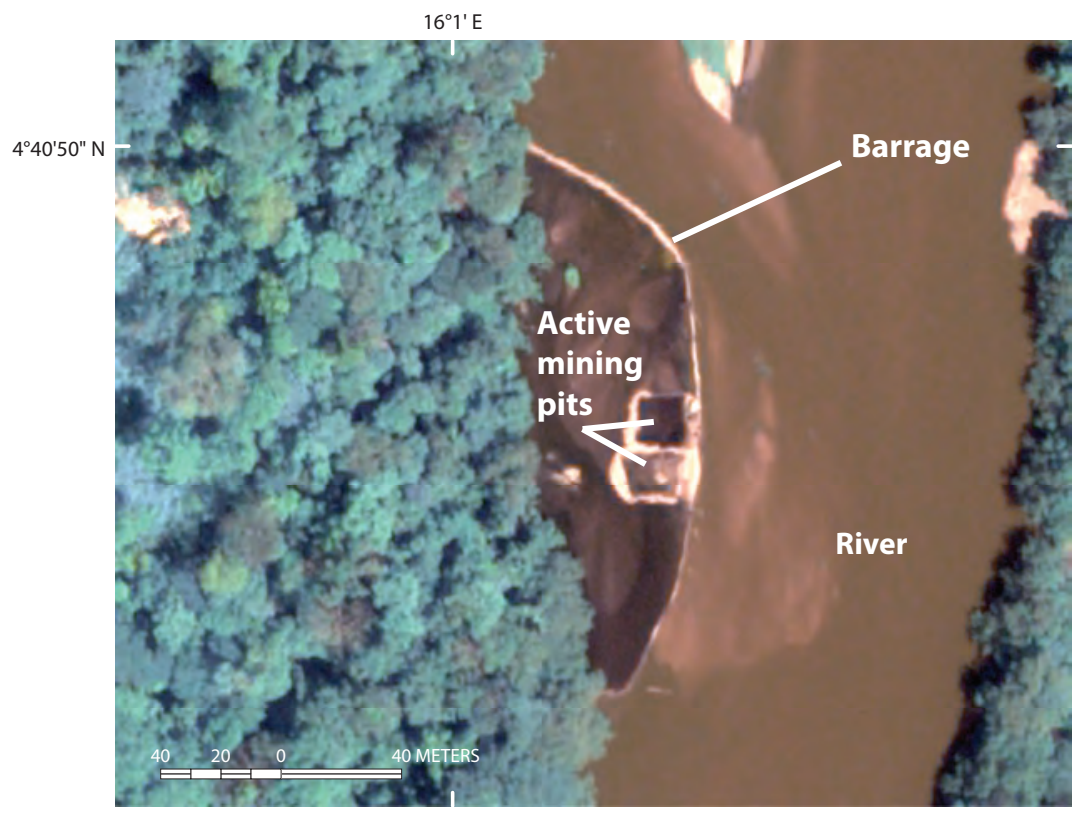

Figure 11. Example of a barrage built into a river channel to stem the flow of water to allow for the digging of pits. Satellite imagery of an area in the Berberati subprefecture of CAR from DigitalGlobe's WorldView-2 satellite, March 27, 2016. 
Table 3. Numeric codes that indicate specific mining activities in the Recent (2013-2017) Mining Activity Dataset.

[ASM_Val, artisanal and small-scale mining value]

\begin{tabular}{cl}
\hline ASM_Val & \multicolumn{1}{c}{ Type of artisanal mining activity } \\
\hline 1 & Nonspecific mining activity \\
2 & Primarily excavation activity (digging, spoil piles) \\
3 & Primarily washing of gravels (in pits or nearby \\
& streams) \\
5 & $\begin{array}{c}\text { Site is currently inactive, but shows signs of previous } \\
\text { mining activity }\end{array}$ \\
\hline
\end{tabular}

numeric code indicating the type of mining activity observed (values specified in table 3), and the most recent year of mining activity observation from satellite imagery.

Because satellite imagery was not acquired for the full extent of CAR, the resultant dataset cannot be considered an exclusive record of diamond mining activity in the country. Although it is possible there are artisanal mine sites beyond the extent of the observed area, the Recent (2013-2017) Mining Activity Dataset represents the best available record of ASM activity and mining in CAR at the time of publication.

\section{Accuracy Assessment in the Carnot Region}

The accuracy of the Recent (2013-2017) Mining Activity Dataset was assessed within the Carnot region by comparing it to field data collected by the U.S. Agency for International Development's (USAID) Property Rights and Artisanal Diamond Development II (PRADD II) project. Between August 1, 2016, and January 30, 2017, the PRADD II project staff visited many artisanal mine sites throughout the Carnot region and collected GPS points of pit locations. Of the 262 GPS points independently collected by this mapping endeavor, 65 field sites fell within or immediately adjacent to gridcells selected as suitable for current mining in the Recent (2013-2017) Mining Activities Dataset and were used to assess the dataset's accuracy (fig. 12). These field observations were compared with the points in the Recent (2013-2017) Mining Dataset using a confusion matrix to compare the presence or absence of each.

\section{Preliminary Dataset Comparison}

The amount and extent of diamond mining activity described by the Archival ASM and Diamond Occurrences Dataset was compared to that of the Recent (2013-2017) Mining Activity Dataset to provide a basic understanding of the geographic differences between the two datasets. Although it is tempting to analyze this as a change in mining activity over time, differences between the two datasets, including the type of observation and the spatial extent of observations, makes such analysis inherently biased and inconclusive. Datasets were investigated through aggregation of each by political subprefecture and then by physical watershed boundary. Aggregation of each dataset entailed tallying the number of points (per dataset) that fell within each subprefecture or watershed boundary. The count for each subprefecture was normalized (divided) by the area of that subprefecture, so that the results indicate the density of dataset points (Archival or Recent) per square kilometer for that subprefecture. This procedure was repeated using sixth order watershed boundaries. Strahler (1957) sixth order stream watersheds were chosen because they occur at a scale that allows for both detailed analysis of mining for specific stream reaches and analysis of significant river drainage systems. Each watershed count was then divided by the total area of that watershed to normalize the results for the area of the watershed.

\section{Supporting Geomorphic Data}

Several ancillary datasets were created to improve satellite imagery interpretation and analysis of current diamond occurrence throughout CAR. A hydrologically corrected digital elevation model (DEM) of the entire country was developed from the Shuttle Radar Topography Mission (SRTM) 30-m DEM (National Aeronautics and Space Administration Land Processes Distributed Active Archive Center, 2014). The modified SRTM data were then used to develop geospatial datasets, including stream lines and watershed boundaries. The procedures used to create these datasets are described in the following sections.

\section{DEM Processing}

The globally available 30-m DEM collected by the SRTM was used to model elevation for the extent of CAR. Post-processing of this DEM to prepare it for hydrologic modeling was performed based on the methods of Hellweger and Maidment (1997). These procedures began with the computation of neighborhood statistics, averaging across a $5 \mathrm{~m} \times 5 \mathrm{~m}$ cell window, to smooth out local variance in the elevation values. The DEM was converted from an integer raster to a floating-point raster to enable the storage of elevation values of higher precision. Because the SRTM DEM was created from radar data which tends to incorporate elevation values of the top of dense vegetative canopy, the thick canopy and undergrowth that grows in the stream valleys of CAR causes anomalously higher elevation values in these areas. These anomalously high values in stream valleys interfere with derivative datasets that model the hydrologic flow. To resolve this issue, the major rivers of CAR were manually digitized from the Esri imagery basemap dataset at scales of 1:50,000 or smaller, and incorporated into the DEM to improve computerized modeling of hydrologic flow. This 


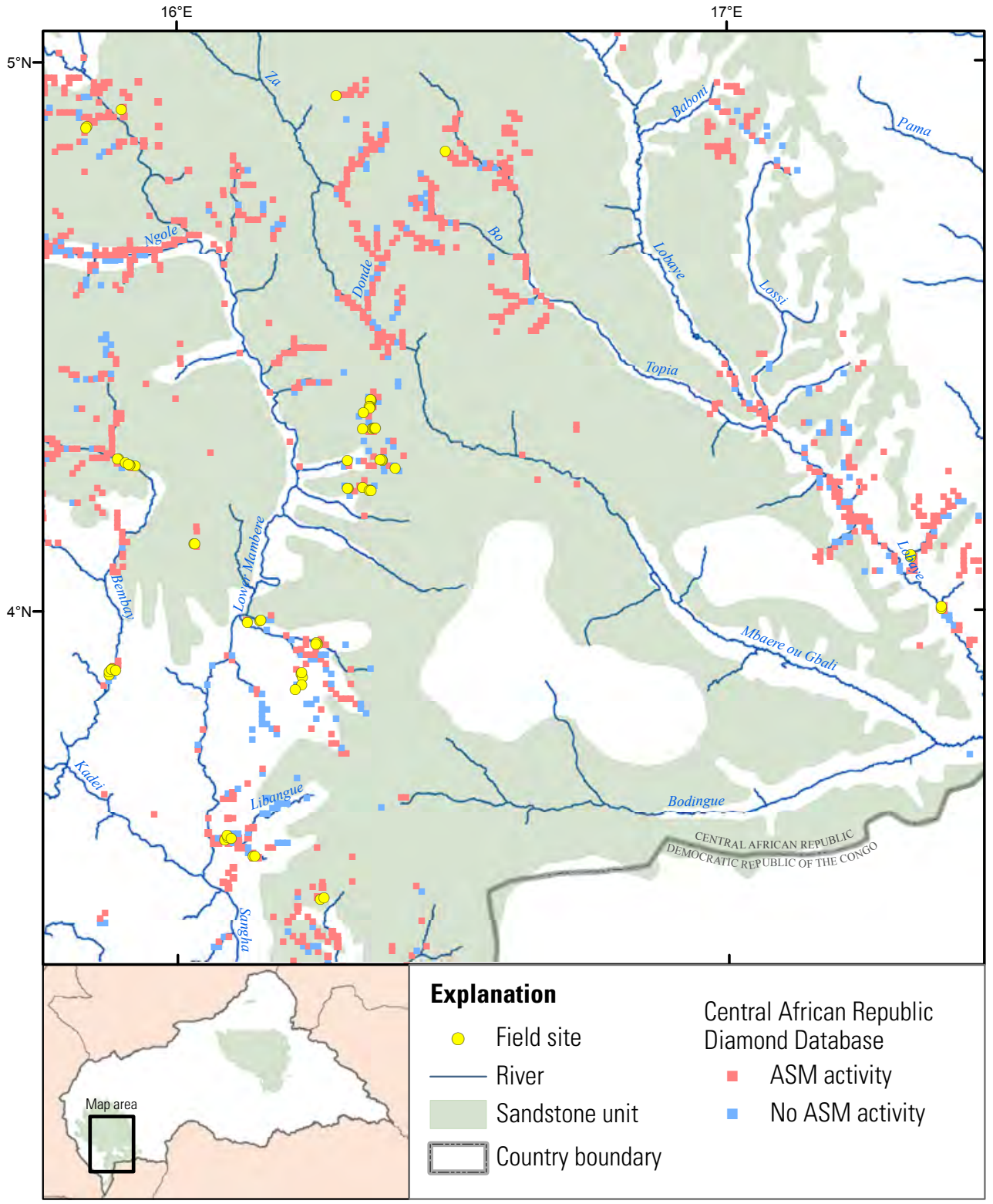

Figure 12. Map showing the field sites visited by the U.S. Agency for International Development's Property Rights and Artisanal Diamond Development II Project between August 1, 2016, and January 30, 2017. ASM, artisanal and small-scale mining.

hydrologically corrected DEM was used for additional DEMrelated analyses and is published in this report (Hellweger and Maidment, 1997). Lastly, to improve visualization of elevation data, a shaded relief dataset was also created and is included with the published data.

\section{Hydrologic Datasets}

Hydrologic datasets, including flowlines and watersheds, were derived from the processed DEM. Several hydrologic processing steps were performed, following the methods of O'Callaghan and Mark (1984). The first step involves the computerized determination of water flow direction from the
DEM. The amount of water flowing through each cell of the DEM is then modeled in the flow accumulation procedure, which uses the DEM and flow direction to calculate, for each cell, the number of DEM cells upslope of that cell. The output was multiplied by the surface area of a DEM gridcell $\left(900 \mathrm{~m}^{2}\right)$ to roughly quantify the amount of water flowing across each gridcell. Cells with large flow accumulation values indicate preferential flow-paths for surface water flow, and may be used to delineate streams. Specification of a threshold value for flow accumulation allows for differentiation of flow-paths from other nonstream areas. This value roughly indicates the drainage area required to generate streamflow, and ultimately determines the density of the stream network (Tarboton and 
others, 1991). In identifying a threshold value for the Central African Republic 30-m DEM, the resultant DEM-derived stream network was matched to the locations and density of stream lines on reference maps, such as the Joint Operations Graphic (JOG) 1:250,000-scale map series (U.S. Army Corps of Engineers, 1966) and the 1:200,000-scale Topographic Map Series of the Central African Republic produced by the Institut Géographique National (1960). It was determined that a flow accumulation threshold value of 7,000 cells, roughly analogous to $6,300,000 \mathrm{~m}^{2}$ or $3.3 \mathrm{~km}^{2}$ of upstream area, matched the stream networks of named streams on the reference maps. The data were reclassified into a new raster dataset wherein gridcells with a flow accumulation value greater than 7,000 cells indicates streamflow and have a value of 1; all other gridcells were given a null value. This stream raster dataset is used for all subsequent hydrologic analysis.

Additional quantitative analysis of the derived streams is based on the Strahler (1957) stream classification system, which assigns a numeric order to each stream reach based on the number and spatial distribution of stream intersections upstream of that reach. Using this numeric ordering of the stream network, the smallest tributary streams are referred to as first order streams, the intersection of two first order streams yields a second order stream reach, the intersection of two second order streams yields a third order stream, and so on. In this classification system the order of a stream reach is proportional to its dimensions, discharge, and watershed size (Strahler, 1957). The Strahler stream order was computed for the streamflow raster using Esri ArcGIS and then converted into a vector polyline dataset for mapping purposes. Additional processing of the raster stream dataset enables the isolation of all streams of a specific order, and the generation of watersheds for that stream order. The polyline stream dataset was attributed with the name of the stream reach, determined from a West Africa 1:250,000-scale map series published by the Army Map Service of the U.S. Army Corps of Engineers in 1963.

Watershed delineation requires an additional processing step, wherein the stream order raster is used to create a stream link raster, in which stream intersections are sequentially numbered. This raster and the flow direction raster described earlier are required inputs for watershed calculation. To delineate the watersheds of second order streams, the stream order raster was reclassified to convert gridcell values less than two to be null values. A new stream link raster was generated for the output, and watersheds were then created as above. This procedure of reclassifying the stream order raster, creating a new stream link raster, and generating watersheds was repeated for each of the nine Strahler stream orders existing within CAR.

The final datasets produced by hydrologic processing include DEM-derived polyline streams, attributed with the Strahler stream order and the name of the stream reach (if available), as well as polygon watershed datasets for each
Strahler stream order. Since these two datasets were produced from a DEM with 30-m resolution, they are appropriate for mapping at scales smaller than 1:100,000.

\section{Surficial Geology and Geomorphology}

Diamond deposits in CAR occur as secondary alluvial deposits, therefore the alluvial landscape was subdivided into functional architectural elements indicative of the surficial geology and geomorphology and mapped. The surficial geology was digitized and modified from work by Lescuyer and Milési (2004); it is shown on the map plate, and the geographic information system (GIS) data are published with this study. Characterization of geomorphologic elements is based on the physical and hydrological processes that created them. The erosion and deposition that occurs as a result of chemical and physical processes have implications for locating alluvial diamond deposits within a diamondiferous watershed. In general terms, stream flow is composed of water and sediments, which are held in suspension or moved along the stream bed. The sediment load carried in suspension is highly dependent on the stream velocity. In lower flow conditions, larger particles, such as sand and gravel, are moved either by rolling or bouncing along the stream bed, and eventually settle to the bottom of the channel. Occasionally, in high flow or flood conditions, large particles will be suspended in turbulent eddies of the water itself and deposited on the stream bed as the velocity diminishes. Over time, as the stream migrates laterally to a new position, these deposited sediments are left behind, marking the previous location of the stream channel. Thus, within diamondiferous watersheds, certain depositional landforms, such as the near-stream alluvium and terraces, have an increased potential to host placer minerals (such as placer diamond deposits).

These landforms can be identified through additional processing and segmentation of the DEM. The processing methods were adapted from the methods of Chirico and Malpeli (2013) and classified the Quaternary-aged sediments into alluvium, terrace, and colluvial hillslope. A three-part process was used to model geomorphology, each of which is describe in greater detail below: (1) geomorphic zones are segmented from relative elevation; (2) a slope-based path distance analysis characterizes erosive and depositional environments; and (3) the geomorphic zones are combined with the path distance analysis to provide geomorphic detail in the surficial geology.

The first stage of geomorphic modeling characterized the surficial geology based on relative height from the current stream channel using the hydrologically corrected 30-m DEM and the stream raster. An elevation value was associated with each stream gridcell by reclassifying the gridcode field of the streams raster (which previously contained a Strahler stream order value) to 1 , then multiplying the result by the hydrologically corrected DEM. The resultant stream raster was 
converted to a point file, wherein the centroid of each stream gridcell was represented by a point with the elevation value of that gridcell. This point file was used to create a triangular irregular network (TIN) representing the lowest local elevations, analogous to the stream valley elevations, in CAR. The TIN was converted to a raster with $30-\mathrm{m}$ cell size and decimal (float) type using linear interpolation and referred to as the "base elevation" raster. Relative elevation, or the vertical change between valley elevations and the terrain surrounding them, was calculated by subtracting the base elevation raster from the hydrologically corrected DEM. The relative-elevation raster was then reclassified into four sequentially numbered zones: low, middle, high, and upland. Each of these geomorphic zones and the associated relative height range is shown in table 4. This reclassified relative-elevation raster is the first part of the combined geomorphic model.

Table 4. Part 1 of the surficial geology and geomorphology model includes zones of relative height.

\begin{tabular}{clc}
\hline Model value & $\begin{array}{c}\text { Geomorphic } \\
\text { zone }\end{array}$ & $\begin{array}{c}\text { Relative height range } \\
\text { (meters) }\end{array}$ \\
\hline 1 & Low & -382.7 to 3.0 \\
2 & Middle & 3.1 to 5.0 \\
3 & High & 5.1 to 10.0 \\
NoData & Upland & 10.0 to $1,034.2$ \\
\hline
\end{tabular}

The second part of the model quantified geomorphic areas produced by depositional and erosive processes based on terrain slope and distance from the hydrologically modeled active channel. Erosional surfaces of the terrain are primarily characterized by steep slopes, and depositional surfaces of the terrain are characterized by low-slope areas that have a large number of upstream cells in the flow-accumulation dataset. A path-distance function in ArcGIS was used to simply model these physical processes, with landform characterization based on Pythagorean distance from the stream. The path-distance function models the depositional process to segment areas in the landscape that are within fluvial valley bottoms. In this part of the model, the value of each gridcell in the output increases with steeper slope and distance from the stream channel, thus depositional areas are segmented as gridcells with low values near stream channels and at the base of more steeply sloped terrain. With increased slope and distance from the stream, the likelihood of a placer deposit development diminishes. The path-distance function in ArcGIS was performed using the raster of the streams as the input feature source data, the hydrologically corrected DEM as the surface raster, and a slope raster (indicating the terrain's rise over run, in degrees) as the cost. The resultant path-distance raster was then reclassified into two classes, with values between 0 and
Table 5. Part 2 of the surficial geology and geomorphology model characterizes erosive and depositional zones by incorporating slope steepness in a path-distance function.

\begin{tabular}{ccc}
\hline Model value & Geomorphology & Path distance value \\
\hline 10 & $\begin{array}{c}\text { Gentle slope, depositional } \\
\text { zone }\end{array}$ & 0 to 150.0 \\
& Steep slope, erosive zone & 150.1 to $146,751.4$ \\
\hline
\end{tabular}

150.0 indicating alluvium (or the depositional alluvial zone) and values 150.1 to $146,751.4$ indicating all other parts of the terrain. The class of alluvium was given a new value of $10^{\mathrm{iii}}$ and the other areas of the terrain were assigned a value of 0 , as shown in table 5.

In part 3 of the model, the results of the first two parts were integrated by adding the raster of reclassified geomorphic zones (values of 1-3) to the raster of reclassified path distance (values 10 and 1). The resultant raster contained classes from 2 to 4 and 11 to 12 . These detailed categories were recombined to represent surficial geology and geomorphic landforms that are useful at the national scale. Values 2 and 11 indicate alluvium, a geomorphic unit of negative or low relative elevation that typically exhibits comparatively deep unconsolidated surficial sediments and gravels deposited by hydrologic processes (Brooks, 2004). In the model published in this study, the alluvium geomorphic unit includes the hydrologically modeled stream channel. Values 3 and 12 indicate terrace landforms, which are microrelief features located in proximity to the alluvium and the present or paleochannel. Terraces are created through earlier cycles of deposition and subsequent change in base level conditions that causes river downcutting, and can provide evidence of previous channel locations (Brooks, 2004). Lastly, value 4 indicates the colluvial hillslope, or the surficial weathered or weakened rock which is primarily affected by gravity-driven downslope movement (Brooks, 2004). The five values of this raster were reclassified into three categories based on the geomorphic landforms they represent at scales smaller than 1:100,000. The final raster model of surficial geology and geomorphology in CAR contains three categories - alluvial, terrace, and colluvial hillslope; all other gridcells have been given a value of No Data. Each of these categories is described in table 6 and is shown on the map plate.

\footnotetext{
iiiThe value 10 distinguishes the elements of part 2 of the geomorphic model from part 1 (which included values of 1-5) even after the two parts are added together.
} 
Table 6. Categories of geomorphic units in part 3 of the surficial geology and geomorphology model.

[-, not applicable]

\begin{tabular}{|c|c|c|}
\hline Model value & Geomorphic unit & Description \\
\hline 1 & Alluvium & $\begin{array}{l}\text { Near-channel area of relative low elevation, typically exhibiting comparatively deep unconsolidated } \\
\text { surficial sediments and gravels deposited by hydrologic processes. }\end{array}$ \\
\hline 3 & Colluvial hillslope & $\begin{array}{l}\text { Area of weathered, unconsolidated surficial material underlain by undifferentiated bedrock, in } \\
\text { which gravitational instability dominates erosive processes. }\end{array}$ \\
\hline
\end{tabular}

\section{Results}

The primary result of this project is the Central African Republic Diamond Database, which consists of two point datasets: (1) the Archival ASM and Diamond Occurrence Dataset and (2) the Recent (2013-2017) Mining Activity Dataset. Together, these datasets describe the geographic distribution of diamond occurrence and mining in CAR (fig. 13). These results are also shown on the map plate. A subset of the supporting geomorphic datasets produced by DEM and hydrologic processing are shown in the following sections: specifically, the hillshade, rivers of Strahler order 5-9, and the sixth order watersheds that are used in the analysis of mining changes over time. A digital copy of the diamond database and supporting geomorphic datasets, including the SRTM DEM and shaded relief, as well as hydrologic datasets (shown on the map plate), are published with this report.

\section{Archival ASM and Diamond Occurrence Results}

The compilation of archival references of diamond occurrences and diamond mine sites in CAR resulted in a point dataset with 3,558 objects, each attributed with a unique ID, a site name (if available), source data, source date, source category, type of diamond location, and geographic coordinates in a standard datum (WGS 1984) and projection (Universal Transverse Mercator [UTM], Zone 34 N). This dataset, symbolized by blue diamonds, is shown in figure 13 and on the map plate. Within the Carnot region, diamond occurrences are principally located in the floodplains of larger streams (Strahler order 4-8); however, there are also some occurrences in upland areas away from the tributaries. Concentrations of occurrences are located around the towns of Berberati and Carnot, as well as to the southeast of the village Nola and to the south-southwest of the village Boda.

Archival reports of diamond occurrences are sparse in the Mouka-Ouadda region (in eastern CAR) compared to the Carnot region, likely a result of lower population density and less historical attention to mineral exploration. In this datasparse region, diamond occurrences are primarily recorded in alluvial floodplains of very large (order 5 and larger) rivers. Concentrations of diamond occurrences can be observed near the towns of Bria, Kembé, Grand Nzako, Ouadda, and Sam Ouandja.

\section{Recent (2013-2017) Mining Activity Dataset}

The interpretation of high-resolution satellite imagery to map current small-scale mining activity resulted in a point geodatabase with 2,560 objects, each attributed with a unique ID, the category of ASM activity observed (ASM _Value), the most recent year of observation (Obs_Yr), the number of image dates in which ASM is recorded at that site (Num_Obs), and geographic coordinates in a standard datum (WGS 1984) and projection (UTM Zone $34 \mathrm{~N}$ ). In this dataset, each location indicates a $1 \mathrm{~km}^{2}$ area of recent (January 1 , 2013-November 28, 2017) small-scale mining activity. This dataset is symbolized by red diamonds in figure 13 and on the map plate. Similar to the archival diamond occurrence dataset, areas of mining activity for the recent observations are generally concentrated in the alluvial floodplains of highorder stream valleys; however, in some places activity has progressed into terrace deposits that are located upslope from the stream floodplain.

Within the Carnot region, areas of artisanal mining activity are found both in the alluvial flat valleys of both high-order and small tributary streams, as well as in low terrace areas of these valleys. The Recent (2013-2017) Mining Activity dataset was found to have an overall accuracy of 75 percent when compared to field observations collected by the PRADD II project. The producer's and user's accuracies for areas of active mining were 96 percent and 78 percent, respectively (table 7).

\section{Map Plate}

A map plate is included with this report to provide geographic and geologic context for the Central African Republic Diamond Database. The Recent (2013-2017) Mining Activity Dataset, symbolized with red diamonds, and the 


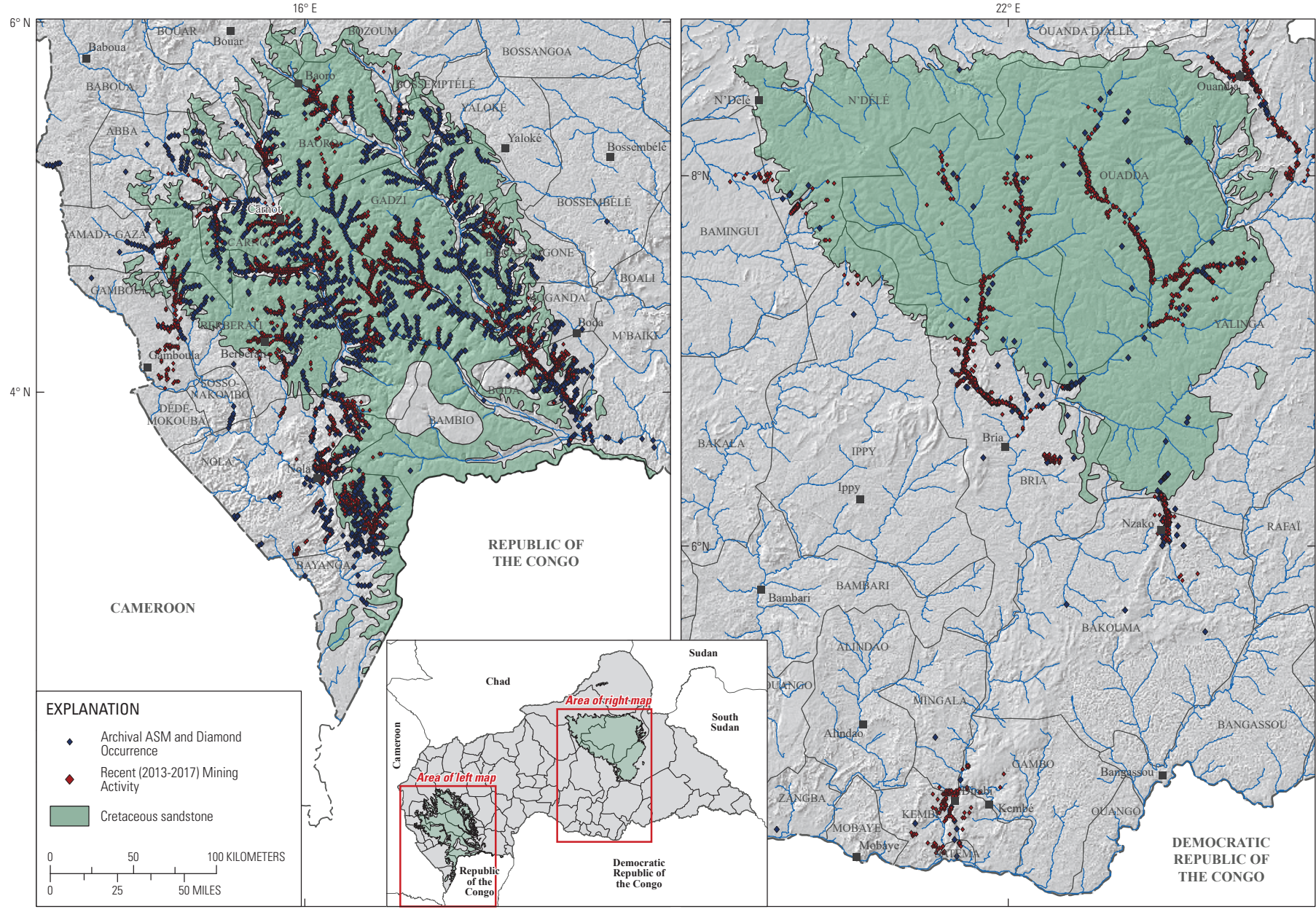

Figure 13. Map showing the Central African Republic Diamond Database, including the Archival Artisanal and Small-Scale Mining (ASM) and Diamond Occurrence Dataset and the Recent (2013-2017) Mining Activity Dataset, which describes the geographic distribution of known small-scale diamond mining activity in the Central African Republic.

Table 7. Accuracy matrix of Carnot region database points.

\begin{tabular}{lccccccc}
\hline \multirow{2}{*}{ Field data } & \multicolumn{2}{c}{ Satellite interpretation (in points) } & & \multicolumn{2}{c}{ Accuracy (in percent) } \\
\cline { 2 - 3 } & Inactive & Active & Row total & & Producer's & User's \\
\hline Inactive & 0 & 2 & 2 & & 0 & 0 \\
Active & 14 & 49 & 63 & & 96 & 78 \\
Column total & 14 & 51 & & & & Overall accuracy & 75 \\
\hline Total points & 65 & Correct points & 49 & & \\
\hline
\end{tabular}


Archival ASM and Diamond Occurrence Dataset, symbolized by pink diamonds, together describe the extent of diamond occurrence and small-scale mining observations for CAR. Ancillary datasets published in this report and represented on the map include the DEM-derived streams layer (Strahler fifth to ninth order), watershed boundary polygons (Strahler sixth order), and the 30-m DEM hillshade.

The point dataset of large towns was created as a subset of a dataset produced by Hearn and others (2001). The polyline roads dataset was created by the Africa Infrastructure Country Diagnostic (AICD) project (World Bank, 2010), and categorizes road segments into functional types (Talvitie, 1996) based on their surface material and condition. This dataset was downloaded from the MapforEnvironment. org website, and subsetted to include only segments of Road_Type 2 and Road_Type 3, to show roads of arterial highway and collector functionality, respectively. Subprefecture boundaries were acquired from F.A. Ngbokoto (Central

African Republic Ministry of Mines, written commun., 2016). Country boundaries were acquired from the U.S. Department of State, Office of the Geographer (2013).

Geology data were modified from Lescuyer and Milési (2004), and describe the distribution of Archean, Proterozoic, Cambrian, Carboniferous, Cretaceous, and Paleogene age geologic units in CAR. Each of these geologic units has been symbolized according to the International Commission on Stratigraphy chronostratigraphic (position) and geochronologic (time) units, as implemented by the USGS Geologic Names Committee (U.S. Geological Survey, 2010). Quaternary (surficial) geology includes: an undifferentiated Quaternary surficial unit, modified from Lescuyer and Milési (2004); and Quaternary-age alluvium, terraces and colluvial hillslopes, adapted from the methods of Chirico and Malpeli (2013). In this surficial geology dataset, landform units (Qa, Qt, and Qc) are modeled from the 30-m hydrologically corrected DEM based on their horizontal and relative vertical distance to the active channel. More specifically, the alluvium (Qa) unit is used to characterize the area immediately adjacent to, and with low relative relief from the streamline, where sediment and small gravels are deposited on the floodplain; the terrace $(\mathrm{Qt})$ unit depicts both the older floodplain of rivers and streams as high and low terraces, and is located peripheral to the floodplain deposits $(\mathrm{Qa})$. The colluvial hillslope $(\mathrm{Qc})$ depicts sedimentary depositional areas along rivers and streams where surficial materials are primarily resultant from gravity-driven erosion and deposition.

\section{Dataset Observations}

The results of the aggregation analysis of the Archival ASM and Diamond Occurrence dataset and the Recent (2013-2017) Mining Activity Dataset are mapped to indicate the number of diamond locations (for each of the datasets in the diamond database) per $1,000 \mathrm{~km}^{2}$ in each subprefecture (fig. 14) or in each watershed (fig. 15). Some general observations regarding the difference in these two datasets between the western Carnot area and the eastern Mouka-Ouadda focus areas follow.

In general, diamond mining in the Carnot focus area has decreased slightly and shifted in geographic distribution. Subprefectures such as Gadzi, Baoro, Boganangone, Berberati, and Nola all contained more than 40 locations in the Archival ASM and Diamond Occurrences Database, and all have dropped to 21-40 locations in the Recent (2013-2017) Mining Activity Dataset. When watersheds are analyzed a similar trend can be observed. Many watersheds throughout the Carnot focus area show fewer diamond occurrences and mine sites in the Recent (2013-2017) Mining Activity Dataset than in the Archival ASM and Diamond Occurrence Dataset. Only one watershed, west of the town of Berberati, increased diamond mining. These specific changes may be impacted by differences between the two datasets, which utilize different observations, cover different geographic extents, and capture different durations of observation. Thus, it can be concluded only that diamond mining activity in the Carnot focus area continues in similar amounts to what has been historically observed.

Although there are similar issues with data coverage for the Mouka-Ouadda focus area, there are more pronounced differences between the two datasets for both the subprefecture analysis and for the watershed analysis. Subprefectures such as Ouadda, Kembé, and Satema all show a greater number of observations per $1,000 \mathrm{~km}^{2}$. Since subprefectures in this focus area can be very large, watershed-based analysis of the two datasets reveals the geographic areas where differences between the two are most pronounced. Watersheds in the vicinity of Sam Ouandja exhibited a substantial number of sites in the Recent (2013-2017) Mining Activity Dataset. Other towns, such as Bria and Grand Nzako, also exhibited evidence of mining activity. Similar to the western Carnot region, in the eastern Mouka-Ouadda region, it may be concluded from these observations that mining activity has continued throughout much of the area where it was historically observed.

\section{Discussion}

\section{Artisanal Mining Remote Sensing Challenges}

Remote sensing methods were used to establish smallscale and artisanal mining activity in both the historical and the current diamond databases. These methods primarily entail the identification of key indicators of artisanal diamond mining activity, and rely heavily on the spatial, spectral, and temporal resolution of available satellite imagery. Ideally, satellite imagery with a spatial resolution between 0.5 and $2 \mathrm{~m}$, including multiple spectral bands, is required to enable identification of soil spectral signatures, the presence of vegetation, and the presence of water in artisanal mining sites. However, the spatial distribution of artisanal mining, 

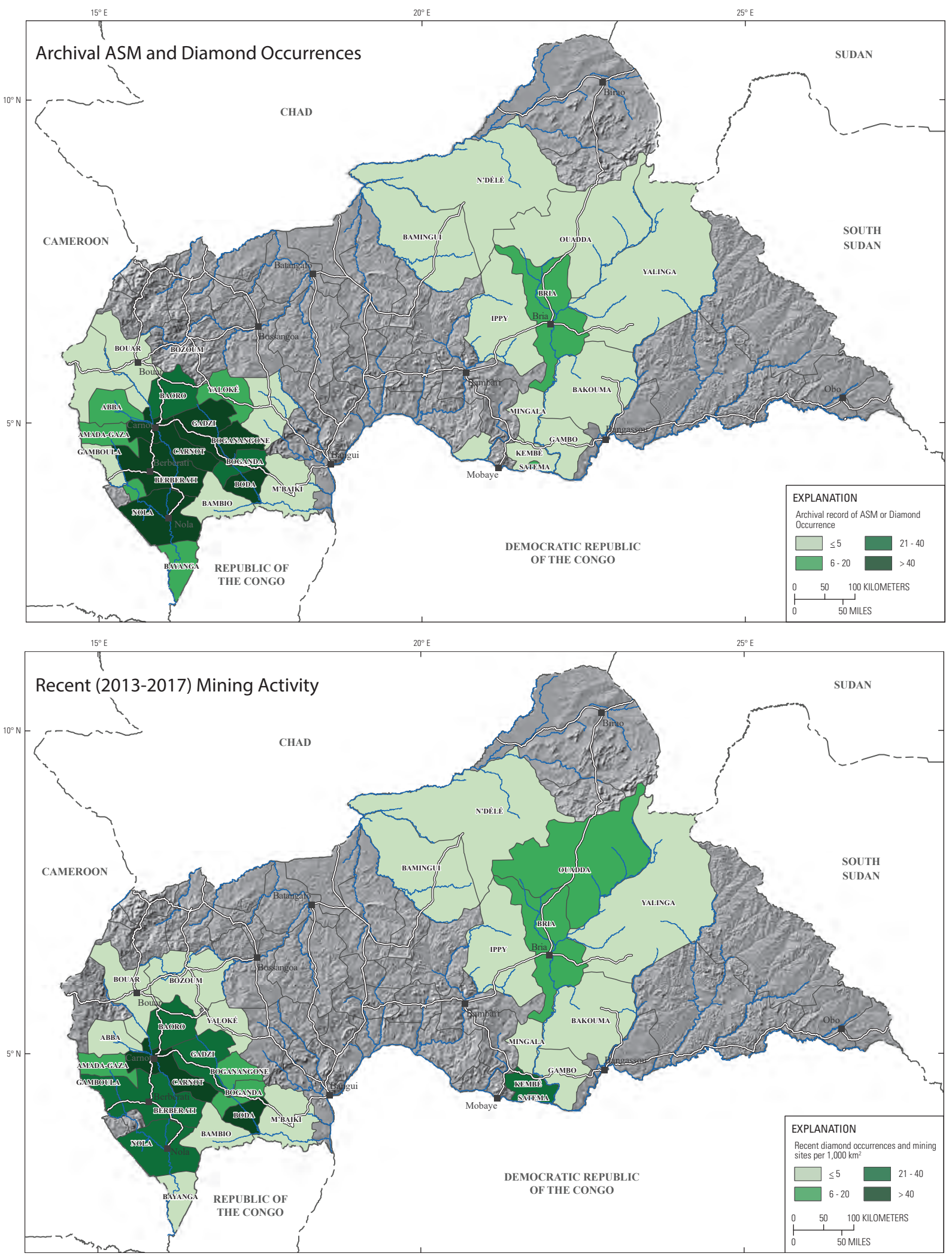

Figure 14. Archival artisanal and small-scale mining (ASM) and Diamond Occurrence results and Recent (2013-2017) Mining Activity results mapped by subprefecture. $\mathrm{km}^{2}$, square kilometers. 


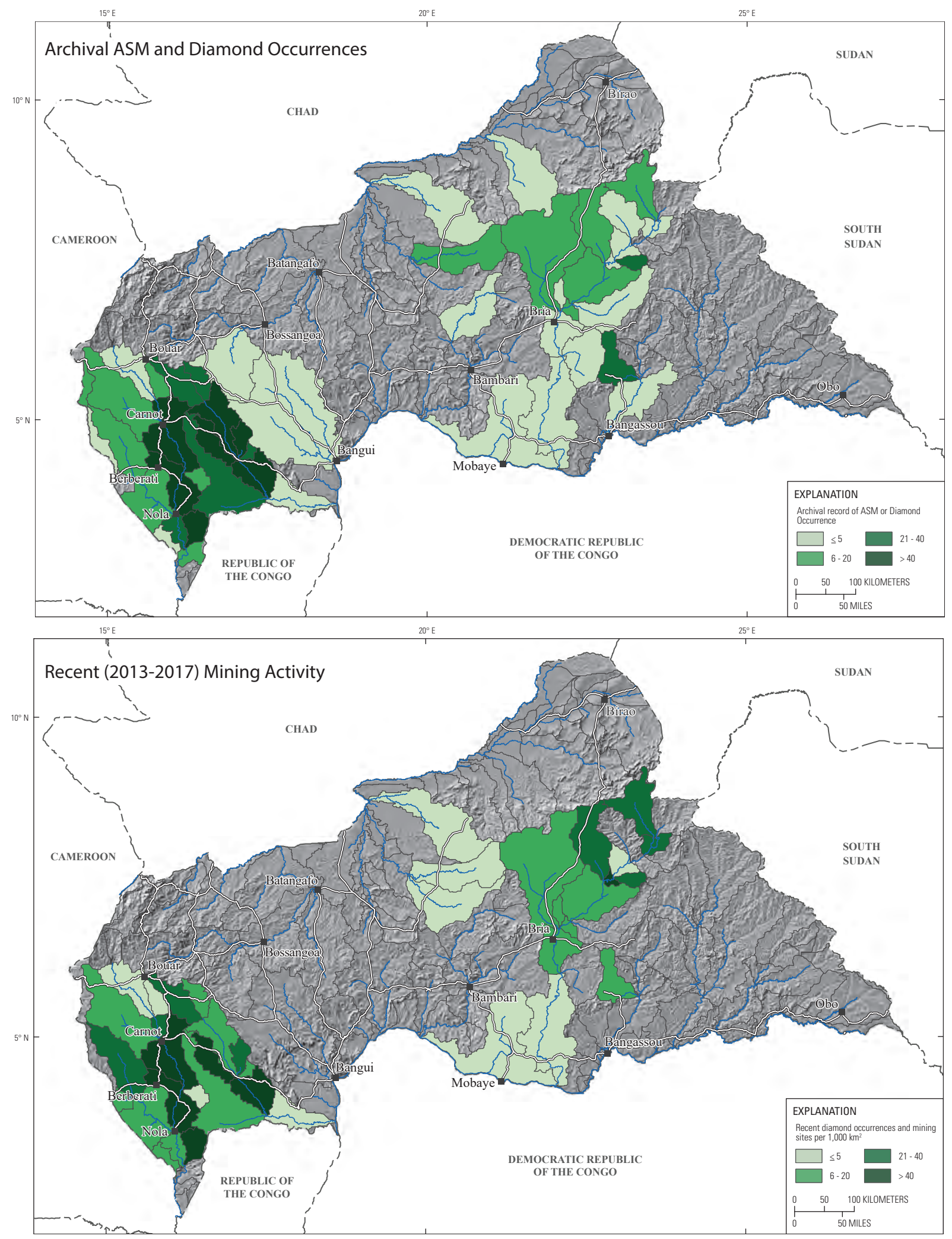

Figure 15. Archival artisanal and small-scale mining (ASM) and Diamond Occurrence results and Recent (2013-2017) Mining Activity results mapped by sixth order watersheds. $\mathrm{km}^{2}$, square kilometers. 
whether widely dispersed like in the Carnot region, or highly localized as in the Mouka-Ouadda region, greatly influences the type and characteristics of imagery acquired, and this in turn influences the detail and accuracy of pit identification. The size of the artisanal mining pits may have regional trends and is also of significant importance in determining the type and resolution of satellite imagery needed. Pits that are smaller than $5 \mathrm{~m}$ in diameter can be difficult to identify in imagery with a resolution coarser than $2 \mathrm{~m}$. Furthermore, specific pit features indicative of a site's activity level, such as the angularity of the pit walls or the presence of water, and small pits $(<5 \mathrm{~m})$ are difficult to identify with imagery spatial resolutions $>5 \mathrm{~m}$. Finally, the temporal resolution of imagery acquired for a site can substantially influence the accuracy of mining identification. Comparison of a site through imagery from different dates can greatly improve visual determination of change and site characteristics, particularly with regard to identification of new mining areas.

Moreover, the short temporal duration of mine sites can significantly impact their field validation. Any temporal lag between the time of satellite image acquisition and the time of field observation is problematic for the accuracy assessment, owing to the dynamic nature of small-scale and artisanal diamond mining methods. Mine site activity typically has a short temporal duration of a few days to a few months, which makes it difficult to validate remotely sensed analyses and interpretations with field data. With regard to the results of validating the Recent (2013-2017) Mining Activity dataset using field data, it is important to acknowledge that USAID data were only collected for active sites. Although this could introduce bias to the results of the accuracy assessment, field data confirming the absence of mining activity is difficult to acquire, as data collection is costly and typically focuses exclusively on the location and size of active mine sites. Lacking field observations of areas with no mining activity, the absence of mining activity in satellite imagery cannot be confirmed. Moreover, field data collection is seldom able to identify new or unknown areas of mining activity that were not previously identified through remote sensing observation. Thus, field validation is useful to confirm mining sites observed through remote sensing, but typically does not address mine sites missed by remote sensing interpretation.

\section{Differences in Diamond Occurrence Between the Carnot and Mouka-Ouadda Focus Areas}

When evaluating the geographic distribution of both the Archival (ASM) and Diamond Occurrence and the Recent (2013-2017) Mining Activity Datasets, the majority of points are located in the western Carnot region, rather than the eastern Mouka-Ouadda region. This distribution of mining occurrences is also indicated by CAR's diamond production statistics, which show that 65-75 percent of diamonds are produced from the Carnot Sandstone (Bardet, 1974; Censier, 1996). There are many complex factors that explain this disproportionate mining activity and production. A significant factor is the higher population density and subsequent larger number of active miners and mine sites within the Carnot region, as compared to the Mouka-Ouadda region. However, the lower reported mining production and diamond occurrences in the latter may also be influenced by the unofficial channels through which diamonds may exit the country (Matthysen and Clarkson, 2013). Related to this is the porous nature of the national border, particularly in the northeastern region, where institutional capacity and central government presence is limited. The remote nature of this region makes it difficult for CAR's government to guard against illegal smuggling and trading of diamonds and other goods. Furthermore, these remote areas in the northern part of the country have been strongly impacted by political conflicts between CAR and the neighboring countries of Chad, Sudan, South Sudan, and Cameroon.

\section{Conclusion}

The Central African Republic Diamond Database represents the most current and complete geographic description of diamond occurrences and mining activity within CAR. Ancillary datasets that allow for improved visualization and analysis of the CAR Diamond Database are also published with this report: the Archival (ASM) and Diamond Occurrence Dataset and the Recent (2013-2017) Mining Activity Dataset. Additional datasets include a 30-m hydrologically corrected DEM and hillshade, rivers attributed with name and Strahler stream order, and watersheds; these datasets were mapped together with both parts of the CAR Diamond Database on the map plate. Spatial analysis of the distribution of these datasets suggested a consistent trend of mining activity throughout both the western Carnot and the eastern Mouka-Ouadda regions of CAR.

\section{References Cited}

A.C.A. HOWE International, Ltd., 1993, Summary report of the exploration of the Bamingui-Bangoran diamond property, Haute Bamingui-Bangoran Administrative District, Republic of Central Africa: A.C.A. HOWE International, Ltd. for Howe Centrafrique S.A.R.L., United Reef Petroleums LTD., Report No. 686, 59 p.

Bardet, M.G., 1974, Geologie du diamant, deuxieme partie: Gisements de diamant d'Afrique, Memoires du Bureau de Recherches Geologiques et Minieres, Orleans, France.

Beauvais, A., and Roquin, C., 1996, Petrological differentiation patterns and geomorphic distribution of ferricretes in Central Africa: Geoderma, v. 73, p. 63-82. 
Blanchot, A., Dumas, J.P., and Papon, A., 1973, Carte géologique de la partie méridionale de l'Afrique de l'ouest a 1/2 000 000: Bureau de recherches géologiques et minieres, Orleans, France, scale 1:2,000,000.

Boulvert, Y., 1996, Étude géomorphologique de la République centrafricaine, Carte à 1/1 000000 en duex feuilles ouest et est ORSTOM éditions, $\mathrm{N}^{\circ} 110$ : Institut Français de recherche scientifique pour le développement en coopération, 264 p., scale 1:1,000,000.

Brooks, A.L., 2004, Geomorphology-A systematic analysis of late Cenozoic landforms (3d ed.): Long Grive, Ill., Waveland Press, Inc., 482 p.

Brown, C., 1983, Bania survey plan and geomorphological interpretation map: CAREMI S.A.R.L., 5 p, scale 1:5,000.

Bureau de Recherches Géologiques et Minières, 1976, Carte des gîtes minéraux du Zäire-à l'échelle du 2000 000: Départment des mines, Direction du service géologique, République du Zaïre, scale 1:2,000,000.

Bureau de Recherches Géologiques et Minières, 2004, Geologie et principales mineralisations d'afrique centrale: BRGM Orléans, France, scale 1:4,000,000.

CAREMI S.A.R.L., 1983, Permis de recherches type A., Mambere Bouli RC4 173 (décret No82 015 du 9 janvier 1982), Prospection de diamant dans la vallee de la riviere Bouli: CAREMI S.A.R.L., survey plan, 2 p., scale 1:5,000.

Censier, C., 1991, Dynamique sédimentaire d'un système fluviatile diamantifère mésozoïque: La formation de Carnot (République centrafricaine), Éditions du BRGM, no 205: Bureau de Recherches Géologiques et Minières, Orléans, France.

Censier, C., 1996, Alluvial diamond deposits in the Central African Republic: Africa Geoscience Review, v. 3, no. 2, p. 217-230.

Censier C., Lang, J., Mbongo, B.H., and Latou, A., 1992, Mise en evidence d'une formation glaciaire paleozoique dans l'est de la Republique Centrafricaine, La formation glaciaire de la Kombele: Comptes Rendus de l'Academie des Sciences, v. 315 , no. 6 , p. $711-715$.

Censier, C., Michel, J.C., and Lamouille, B., 1998, Rapport final du project d'appui au secteur artisanal du diamant en République Centrafricaine (PASAD) [01/09/96-31/08/98]: Rapport BRGM N 2655, 128 p., 1 annexe, no map scale.

Censier, C., and Tourenq, J., 1986, Mise en evidence d'un extension occidentale des gres de Carnot (Republique Centrafricaine) par analyses sedimentologiques comparees de gisement alluvionnaires diamantiferes: Geodynamique, v. 1, no. 1, p. 21-32.
Central Intelligence Agency [2016], Central African Republic: Central Intelligence Agency, The World Factbook 20132016 web page, accessed December 30, 2016, at https:// www.cia.gov/library/publications/the-world-factbook/geos/ ct.html.

Chirico, P.G., Bartélémy, F., and Ngbokoto, F.A., 2010, Alluvial diamond resource potential and production capacity assessment of the Central African Republic: U.S. Geological Survey Scientific Investigations Report 2010-5043, 22 p.

Chirico, P.G., and DeWitt, J.D., 2017, Mapping informal small-scale mining features in a data-sparse tropical environment with a small UAS: Journal of Unmanned Vehicle Systems, v. 5, no. 3, p. 69-91.

Chirico, P.G., and Malpeli, K.C., 2013, Reconnaissance investigation of the rough diamond resource potential and production capacity of Côte d'Ivoire: U.S. Geological Survey Scientific Investigations Report 2013-5185, 46 p.

Chirico, P.G., and Malpeli, K.C., 2014, The role of conflict minerals, artisanal mining, and informal trading networks in African intrastate and regional conflicts: Small Wars Journal, 18(11), accessed July 27, 2018 at $\mathrm{http} / / /$ smallwarsjournal.com/jrnl/art/the-role-of-conflictminerals-artisanal-mining-and-informal-trading-networksin-african-int.

Choubert, G., Faure-Muret, A., Mestraud, J.L., and Pallister, J.W., 1968, Carte tectonique international de l'Afrique: International Geological Congress, Commission for the World Geological Map and Sub-commission for the World Tectonic Map, scale 1:5,000,000.

Danielson, J.J., and Gesch, D.B., 2011, Global multiresolution terrain elevation data 2010 (GMTED2010): U.S. Geological Survey Open-File Report 2011-1073, 26 p.

Ghura, D., and Benoît, M., 2004, Political instability and growth-The Central African Republic: IMF Working Paper, African and Asia and Pacific Departments, WP/04/80, International Monetary Fund, 22 p.

Giroux, J., Lanz, D., and Sguaitamatti, D., 2009, The tormented triangle - The regionalisation of conflict in Sudan, Chad, and the Central African Republic: Crisis States Working Papers Series no. 2, Working Paper no. 47, Regional and global axes of conflict, Crisis States Research Centre, DESTIN Development Studies Institute LSE, London, UK, 22 p.

Hearn, P.P., Jr., Hare, T.M., Schruben, P., Sherrill, D., LaMar, C., and Tsushima, P., 2001, Global GIS database; digital atlas of Africa: U.S. Geological Survey Data Series 62-B, CD-ROM. 
Hellweger, F., and Maidment, D., 1997, AGREE-DEM surface reconditioning system: University of Texas, accessed April 26, 2017, at http://www.ce.utexas.edu/prof/maidment/ GISHYDRO/ferdi/research/agree/agree.html.

Institut Géographique National, 1960, Topographic map series of the Central African Republic: Institut Géographique National, Paris, France, 1:200,000 scale.

International Crisis Group, 2007, Central African RepublicAnatomy of a phantom state: International Crisis Group, Africa report N ${ }^{\circ} 136-13$ Dec 2007, Brussels, Belgium, 48 p.

International Crisis Group, 2014, The Central African crisisFrom predation to stabilisation: International Crisis Group, Africa Report N`219-17 Jun 2014, 42 p.

Kauffmann, M., Caravaggi, I., Louvrier, C., Al Khudhairy, D.H.A., Chirico, P.G., Malpeli, K.C., and DeWitt, J., 2014, Joint EU-US methodology for monitoring alluvial diamond mining activities in the Central African Republic: A European Commission (JRC) and United States Geological Survey (USGS) Report, JRC90218, 29 p.

Kimberley Process, 2017, About the Kimberley Process: Kimberley Process web page, accessed April 28, 2017, at https://www.kimberleyprocess.com/en/about.

Kimberley Process Certification Scheme, 2013, Administrative decision on the Central African Republic [temporary suspension]: Kimberley Process Certification Scheme Intersessional Meeting, Kimberley, South Africa, May 23, 2013.

Kimberley Process Certification Scheme, 2014, Administrative decision ensuring that diamonds from the CAR are not introduced into legitimate trade: Kimberley Process Certification Scheme Intercessional Meeting, Shanghai China, June 9-12, 2014.

Kimberley Process Certification Scheme, 2015a, Administrative decision ANNEX, operational framework for resumption of exports of rough diamonds from the Central African Republic: Kimberley Process Certification Scheme Intersessional Meeting, Luanda, Angola, June 22-26, 2015.

Kimberley Process Certification Scheme, 2015b, Administrative decision on resumption of exports of rough diamonds from the Central African Republic: Kimberley Process Certification Scheme Intersessional Meeting, Luanda, Angola, June 22-26, 2015.

Le Billon, P., 2008, Diamond wars? Conflict diamonds and geographies of resource wars: Annals of the Association of American Geographers, v. 98, no. 2, p. 345-372.
Lescuyer, J.L., and Milési, J.P., 2004, Africa GIS and SIGAfrique network - Geological and metallogenic information system, tools for sustainable development: Colloque de Géologie Africaine, 20éme, France.

Malpeli, K.C., and Chirico, P.G., 2014, A sub-national scale geospatial analysis of diamond deposit lootability-The case of the Central African Republic: The Extractive Industries and Society, v. 1, no. 2, p. 249-259.

Martini, J., and Bowles, M., 1994, Metallogenic map of the Republic of Congo: Ministère des mines et de l'énergie (Brazzaville, Congo), scale 1:1,000,000.

Matthysen, K., and Clarkson, I., 2013, Gold and diamonds in the Central African Republic-The country's mining sector, and related social, economic and environmental issues: International Peace Information Service report, Antwerp, Belgium, $36 \mathrm{p}$.

Mestraud, J.L., and Bessoles, B., 1982, Géologie et ressources minérales de la République Centrafricaine-État des connaissances à fin 1963: Bureau de Recherches Géologques et Minières, Orléans, France, Mémoires du BRGM, no. 60 , tableau 3, 185 p., map with text, scale 1:1,500,000.

Milési, J., Toteu, S.F., Deschamps, Y., Feybesse, J., Lerouge, C., Cocherie, A., Tchameni, R., Moloto-A-Kenguemba, G., Kampunzu, F., Nichol, N., Duguey, E., Leistel, J., Saint-Martin, M., Ralay, F., Heinry, C., Doumnang, Mbaigane, J., Chêne, F. Monthel, J., Boutin, P., and Rolin, P., 2004, Geology and major ore deposits of central Africa : Bureau de Recherches Géologques et Minières, Orléans, France, scale 1:4,000,000.

National Aeronautics and Space Administration Land Processes Distributed Active Archive Center, 2014, Shuttle Radar Topography Mission 1 Arc-Second Global, (ver. 3): National Aeronautics and Space Administration Earth Observing System Data Information System, Land Processes Distributed Active Archive Center, Sioux Falls, South Dakota, accessed January 1, 2016, at https://earthexplorer.usgs.gov.

Ngoupana, P-.M., 2014, Central African Republic's capital tense as ex-leader heads into exile: Reuters, January 11, 2014, accessed December 30, 2016, at https://uk.reuters.com/article/uk-centralafrican/centralafrican-republics-capital-tense-as-ex-leader-heads-intoexile-idUKBREA090O220140111.

Nguimalet, C.R., 2004, Dynamique et impacts de l'extraction $\mathrm{du}$ diamant dans les lits fluviaux des rivières Boungou et Pipi en République centrafricaine: Geo-Eco-Trop, v. 28, no. 1-2, p. 39-52. 
O'Callaghan, J.F., and Mark, D.M., 1984, The extraction of drainage networks from digital elevation data: Computer Vision, Graphics, and Image Processing, v. 28, no. 3, p. 323-344.

Petit, M., 1985, A provisional world map of duricrust, in Doublas, I., and Spencer, T., eds., Environmental change and tropical geomorphology: London, George Allen \& Unwin, p. 269-279.

Schlüter, T., 2006, Geological atlas of Africa: Berlin, SpringerVerlag, $272 \mathrm{p}$.

Shiochet, C.E., Yan, H., and Karikari-apau, N., 2013, Central African Republic president flees capital amid violence, official says: CNN, March 25, 2013, accessed December 30, 2016, at http://www.cnn.com/2013/03/24/world/africa/ central-african-republic-unrest/index.html.

Smith, D., 2014, Christian threats force Muslim convoy to turn back in CAR exodus: The Guardian, February 14, 2014, accessed December 30, 2016, at https://www.theguardian. com/world/2014/feb/14/muslim-convoy-central-africanrepublic-exodus.

Spittaels, S., and Hilgert, F., 2009, Mapping conflict motives - Central African Republic: International Peace Information Service Report, Antwerp, Brussels, 46 p.

Strahler, A.N., 1957, Quantitative analysis of watershed geomorphology: EOS Transactions, American Geophysical Union, v. 38, no. 6, p. 913-920.

Sutherland, D.G., 1985, Geomorphological controls on the distribution of placer deposits: Journal of the Geological Society, v. 142, no. 5, p.727-737.

Talvitie, A., 1996, Functional classification of roads: Annual Meeting of the Transportation Research Board, Washington D.C., January 1996.

Tarboton, D.G., Bras, R.L., and Rodriguez-Iturbe, I., 1991, On the extraction of channel networks from digital elevation data: Hydrological Processes, v. 5, p. 81-100.

The Sentry, 2015, Country brief - Central African Republic, July 2015: The Sentry web page, accessed February 14, 2017, at https://thesentry.org/reports/car/.

United Nations Development Programme, 2016, Human development report 2016-Central African Republic: United Nations Development Programme web page, accessed June 19, 2017, at http://hdr.undp.org/en/countries/ profiles/CAF.
U.S. Army Corps of Engineers, 1963, West Africa topographic map, Central African Republic-Cameroon, Berbérati quadrangle NB 33-15: Army Map Service, Washington D.C., scale 1:250,000.

U.S. Army Corps of Engineers, 1966, Joint operations graphic (ground) series, Central African Republic, NB 35-9, NB 34-13, NC 34-10, NC 34-11, NC 34-15: Army Map Service, Washington, D.C., scale 1:250,000.

U.S. Department of State, Office of the Geographer [2013], Africa-3m Simplify, GIS dataset: U.S. Department of State Office of the Geographer web page, accessed January 30, 2015, at https://catalog.data.gov/harvest/geonode-state-csw.

U.S. Geological Survey, 2010, Divisions of geologic timeMajor chronostratigraphic and geochronologic units: U.S. Geological Survey Fact Sheet 2010-3059, 2 p.

Vaaldiam Resources Ltd., 2005, Annual Report 2005: Vaaldiam Resources Ltd., 44 p.

Working Group of Diamond Exports, 2012, "Footprint" or characteristics of the diamond production from the Eastern region around Bria in the Central African Republic (CAR) Report: Kimberley Process web page, accessed June 19, 2017, at https://www.kimberleyprocess.com/en/2012-wgdefootprint-car-final.

World Bank, 2005, Africa infrastructure country diagnostic (AICD), Central African Republic (CAR) Roads, GIS dataset: Data acquired by AICD, Tecsult International, Ltd., Ministère du Transport (MT), Ministère de l'Équipement et du Désenclavement, Entretient des Routes (MEDER), and Aviation Civile (AC), hosted online at Map for Environment web page, uploaded March 16, 2016, accessed July 11, 2017, at https://mapforenvironment.org/layer/ info/125/\#5.71/.

World Bank, 2010, A comprehensive approach to reducing fraud and improving the contribution of the diamond industry to local communities in the Central African Republic: World Bank Report no. 56090-CF, Oil, Gas and Mining Policy Division, $84 \mathrm{p}$.

World Bank, 2017, The World Bank in Central African Republic - Overview: World Bank web page, accessed January 5, 2018, at http://www.worldbank.org/en/country/ centralafricanrepublic/overview.

Yarmolyuk, V.A., ed., 1980, Map of mineral resources of Africa: Mingeo, Moscow, USSR, scale 1:5,000,000. 
Manuscript was approved on July 20, 2018

For more information about this publication, contact Director, Eastern Geology and Paleoclimate Science Center U.S. Geological Survey

National Center, MS 926A

12201 Sunrise Valley Drive

Reston, VA 20192

Or visit our website at https://geology.er.usgs.gov/egpsc/

Publishing support was provided by the USGS Science Publishing Network, West Trenton and Reston Publishing Service Centers 
